\title{
Visual Poetry after Modernism: Elizaveta Mnatsakanova
}

\section{Citation}

Sandler, Stephanie. 2008. “Visual Poetry after Modernism: Elizaveta Mnatsakanova.” Slavic Review 67 (3): 610-641.

\section{Published Version}

$10.2307 / 27652942$

\section{Permanent link}

http://nrs.harvard.edu/urn-3:HUL.InstRepos:12311541

\section{Terms of Use}

This article was downloaded from Harvard University's DASH repository, and is made available under the terms and conditions applicable to Other Posted Material, as set forth at http:// nrs.harvard.edu/urn-3:HUL.InstRepos:dash.current.terms-of-use\#LAA

\section{Share Your Story}

The Harvard community has made this article openly available.

Please share how this access benefits you. Submit a story.

\section{Accessibility}




\title{
Visual Poetry after Modernism: Elizaveta Mnatsakanova
}

\author{
Stephanie Sandler
}

Can we think about twentieth-century Russian poetry as anything other than the Age of Mandel'shtam? The charismatic effect of Osip Mandel'shtam, fully described and analyzed by Gregory Freidin more than twenty years ago, remains unmatched. ${ }^{1}$ Other poets have taken strong hold over readers' imaginations, but in particular ways: Anna Akhmatova as the emblematic woman poet, Marina Tsvetaeva as a linguistic wizard, Boris Pasternak as a creator of startling rhetorical figures. The turn to singular alternatives, however, may not take us very far in any fundamental revision of early twentieth-century poetry, for it stays with the unitary model of cultural dominance that has long held its own traps for Russian culture. One poet, one tsar, one faith - these insistent acts of primacy have limited our grasp of the complexity of cultural activity in Russia, to say nothing of their disastrous political consequences.

I propose considering some new combinations of so-called Silver Age poets as we look to understand their legacy more fully. ${ }^{2}$ Brighter light is shed on literary culture when we recognize the unexpected connections that poets make with their predecessors. Uniting somewhat disparate figures can help make sense of some of the most challenging poets of the contemporary period, and the two earlier poets whom I address here-Velimir Khlebnikov and Andrei Belyi-are immensely challenging in their own ways. In the case of Khlebnikov, the challenge is interpretive. Despite excellent work on his poetry, we have yet to come to terms with his powerful and strangely under-studied effect. He was as charismatic (in his elusiveness) as Mandel'shtam, and perhaps more resistant to containment within a single aesthetic system, even one of his own devising. This is less true of the poet with whom I will pair him, the symbolist Belyi. Belyi's poetic systems were elaborated in his own extensive theoretical writings, and Boris Tomashevskii praised him as Russia's verse theorist

The author gratefully thanks Elizaveta Mnatsakanova for providing unpublished materials and for permitting their publication as well as the publication of the images. Additional help from Gerald Janecek, John Malmstad, and from Slavic Review's reviewers is also much appreciated, as is superb assistance from Stuart Butcher in reproducing the images.

1. See Gregory Freidin, A Coat of Many Colors: Osip Mandelstam and His Mythologies of Self-Presentation (Berkeley, 1987). I do not mean to diminish the significance of Mandel'shtam's poetry, particularly as someone who gratefully came to understand whatever I know about Russian modernism through his poetry. My experience is perhaps more typical of graduate students trained before 1990, but consider the influential essays that still appear, for example, Sergei Averintsev, "Tak pochemu zhe vse-taki Mandel'shtam?" Novyi mir, no. 6 (1998).

2. The term Silver Age has been called into question by Omry Ronen, The Fallacy of the Silver Age in Twentieth-Century Russian Literature (Amsterdam, 1997). See also Aleksandr Lavrov, “'Serebrianyi vek' i/ili 'panteon sovremennoi poshlosti,'” Novoe literaturnoe obozrenie [hereafter NLO], no. 51 (2001): 240-47. 
of genius. ${ }^{3}$ Belyi also stands as the creator of poetic prose in Russian, an achievement for which he was revered by Vladimir Nabokov. He was a "poet's poet" in perhaps a different way from Khlebnikov: his technical knowledge and his poetic inventiveness remain legendary.

I bring together Khlebnikov and Belyi at the prompting of the visual poetry of Elizaveta Mnatsakanova (b. 1924). Visual poetry is her preferred term for her work, but we should not imagine that her poetry appeals only to the eye. With their phonic layering, intricate connections among words, and puns, Mnatsakanova's poems are acoustical feats; the poet's use of visual imagery, calligraphy, and complex linear layouts demand that a reader engage with the look of words on the page as much as with the sounds and meanings the words conjure up. That double insistence makes Mnatsakanova different from nearly every other visual poet working in Russian (Ry Nikonova and Sergei Sigei, for instance), and it also pushes readers to see more complex lines of descent in the cultural tradition Mnatsakanova inherits. Khlebnikov and Belyi, different as they are, carved out paths down which Mnatsakanova has progressed. The purpose of this article is to assess more fully her radically innovative work as well as to suggest that poets from the first third of the twentieth centuryparticularly if we are willing to reconfigure alliances and connections among them - remain an important provocation to the cultural practice we call poetry.

Mnatsakanova's achievements offer the occasion for one further point of argument, and that has to do with how one approaches poetry more broadly. Her work, like that of both Belyi and Khlebnikov, can be difficult to comprehend on initial readings, and thus it might invite and would certainly reward close reading. Some close reading will follow, but with the larger goal of giving an account of the poetry's engagement with the senses. Rather than focusing exclusively on the semantic density and visual richness of the work, and thus implying that such engagement helps us appreciate the mastery of a singular poet, I argue that her work also opens out toward larger theoretical questions about the sensory experience of attending to and absorbing poetry, particularly poetry that challenges the superiority of one set of sense impressions over another. In that turn, I am inspired by Susan Stewart and Charles Altieri, who have sought to go beyond both a materialist and a formalist approach to poetic texts. ${ }^{4}$ Like them, I emphasize the sensuous nature of literary experience. Mnatsakanova's intense work with sound, and her use of words as units of meaning and as arrangements of letters on the visual field of a page, means that her poems require a perceptual fluidity of readers. ${ }^{5}$ The presence of visual imagery pushes that requirement still further and suggests

3. As recalled by Vladislav Kholshevnikov; cited in Mikhail Gasparov, "Belyi-stikhoved i Belyi-stikhotvorets," in Gasparov, Izbrannye trudy, 3 vols. (Moscow, 1997), 3:424.

4. Charles Altieri, "The Sensuous Dimension of Literary Experience: An Alternative to Materialist Theory," New Literary History 38, no. 1 (2007): 71-98; Susan Stewart, Poetry and the Fate of the Senses (Chicago, 2002).

5. On perceptual fluidity, see Ingrid Monson, "Hearing, Seeing, and Perceptual Agency,” Critical Inquiry 34, no. S2 (2008): S36-S58. 
that poems can reach beyond language. In its sights, sounds, and even its feel, Mnatsakanova's work offers new ways to see the state of Russian poetry past, present, and future.

\section{The Khlebnikov Effect}

Velimir Khlebnikov led a twofold revolution in poetry, based on mathematics and on morphology. His writings insist that the look of poetry matters, although Khlebnikov's indifference to the appearance of his work in print was legendary. He is unlike visual poets who labor over each page or frame of poetry, yet his work is stunningly visual. As one scholar has put it, he "saw with an artist's eye," and his poems are filled with metaphors for the cognitive and sense processes of sight. ${ }^{6} \mathrm{He}$ was a maker of precise and fantastic drawings, from his youthful bird studies to his later architectural inventions. His fascination with mathematical models for thought and his turn to concepts and logical devices from math have had long-lasting and unpredictable effects. Slavists have done excellent work on his mathematical modeling, making his most obscure and far-fetched theoretical writings available. ${ }^{7}$ Marjorie Perloff has studied numerical symbolism in Khlebnikov and William Butler Yeats, and she and others have emphasized how Khlebnikov's calculations and formulae imagined a world in which verbal logic was not supreme. ${ }^{8}$ Numbers take our minds to places where words cannot go, and numerical symbols communicate as if bypassing words. Numbers also introduce the concept of pure sequencing into a verbal medium, poetry, that relies on counting for its very structure: one counts syllables in quantitative poetic systems, as in French and Polish poetry; one counts stresses and the unstressed syllables between them in the syllabo-tonic system, as in the Russian- and the English-language traditions. One counts lines to make stanzas, and one visually inspects the alternations of rhyme and rhythm in repeating sequences. Numbers, when thematized, have the potential to remind readers how much silent counting occurs in our reception of poetry. ${ }^{9}$

6. Robin Milner-Gulland, "Khlebnikov's Eye," in Catriona Kelly and Stephen Lovell, eds., Russian Literature, Modernism, and the Visual Arts (Cambridge, Eng., 2000), 200.

7. Velimir Khlebnikov, Doski sud'by (Moscow, 2000). This volume includes Vasilii Babkov, "Konteksty Dosok sud'by," the most detailed analysis of his mathematical theories, including his views of time. See also Ronald Vroon, "Metabiosis, Mirror Images and Negative Integers: Velimir Chlebnikov and His Doubles," in Willem G. Weststeijn, ed., Velimir Chlebnikov (1885-1922): Myth and Reality: Amsterdam Symposium on the Centenary of Velimir Chlebnikov (Amsterdam, 1986), 243-90.

8. Marjorie Perloff, "Numerical Symbolism: Yeats, Khlebnikov, and the Mathematics of Modernism," in Perloff, Poetic License: Essays on Modernist and Postmodernist Lyrics (Evanston, 1990), 71-98; see also her essay "Khlebnikov's Soundscapes: Letter, Number, and the Poetics of Zaum," in Perloff, Twenty-First Century Modernism: The "New" Poetics (Malden, 2002), 121-53. In addition, Alexander Spektor has written a fine paper resonantly entitled "V-Khlebnikov" (unpublished paper, 2003). On the larger Russian context for Khlebnikov's visual poetics, see Ian Chesley, "Handwriting, Typography, Illustration: The Visual Word of the Russian Avant-Garde" (PhD diss., Harvard University, 2007).

9. Khlebnikov made numbers a subject of some of his poems; see, for example, a short poem in praise of numbers, "Chisla": Velimir Khlebnikov, Sobranie sochinenii, ed. 
Like mathematics, morphology fascinated Khlebnikov. The laws of numbers and the laws of word formation do not coincide in his work, but in both areas he sought transparency of structure and a perfect knowledge of origins. The Moscow poet Ol'ga Sedakova has noted that Khlebnikov's morphological pursuits were meant to uncover lost, often pre-Christian semantic associations for words. ${ }^{10}$ The result could be a poem in which a recognizable root, laughter, is turned into a set of variations where syntax makes the meaning remarkably accessible, as in "Zakliatie smekhom" (Incantation by laughter), or the result could be closer to the ideal of zaum' as in "Bobeobi." It is no accident that riffs on the poem "Bobeobi pelis' guby" open and conclude the music CD Zhilets vershin, Aleksei Khvostenko's and the rock group Auktsyon's remarkable recording based on the poetry of Khlebnikov; a much larger study of the Khlebnikov effect on contemporary poetry and culture would need to attend to performances as different as those of Khvostenko, Mnatsakanova, Dmitrii Prigov, Sedakova, and Arkadii Dragomoshchenko, to name only a few contemporary poets. Dragomoshchenko's poetic practice would also open out to comparing the Khlebnikov effect on American poetry, where an important role has been played by his translator and friend, the Language poet Lyn Hejinian. ${ }^{12}$

\section{Belyi, Musicality, and the Magic of the Poetic Word}

No such claims about American poetry could be made for the effect of Belyi, although his work is surely as radically innovative and as significant in the history of poetry as that of Khlebnikov. Belyi's immediate successors, chief among them Vladimir Maiakovskii, imbibed a great deal from his theoretical and practical work in verse, but it is harder to see the effect on later poets. Mnatsakanova's return to Belyi is distinctive, and it involves the larger sense of a poetic project rather than thematic or verbal borrowings, for the most part. A return to Belyi is no simple matter, however: despite some excellent scholarship and particularly strong work on his prose, Belyi never attracted anything like the critical industry surround-

R. V. Duganov, 6 vols. (Moscow, 2000-2006), 1:239; for a translation, see Velimir Khlebnikov, Selected Poems, trans. Paul Schmidt, ed. Ronald Vroon (Cambridge, Mass., 1997), 39. No contemporary poet produced a more radical extension of this idea than Dmitrii Aleksandrovich Prigov, in his fabulous performance of "Schitanie," as recorded with the Mark Pekarskii Ensemble in 1990, released 2005 under the Otdelenie Vykhod label, entitled Prigov Pekarskii Rubinshtein.

10. O. A. Sedakova, "Kontury Khlebnikova: Nekotorye zamechaniia k stat'e Kh. Barana," in A. E. Parnis, ed., Mir Velimira Khlebnikova: Stat'i, issledovaniia, 1911-1998 (Moscow, 2000), 574. One could compare this observation to Sedakova's recovery of lost Old Church Slavic meanings in her own poetry. On that topic, see her comments in an interview with Dmitrii Bavil'skii, "V slovakh, a ne putem slov," Topos, 15 March 2003.

11. For the poems, see Khlebnikov, Sobranie sochinenii, 1:198 ("Bobeobi") and 1:209 ("Zakliatie smekhom”). Translations appear in Khlebnikov, Selected Poems, 30.

12. See, for example, Hejinian's translations of his work, including his long poem that pays tribute to Khlebnikov, "Nasturtium as Reality," in Dragomoshchenko, Description, trans. Lyn Hejinian and Elena Balashova (Los Angeles, 1990), 93-112. 
ing Khlebnikov's writings. Trying to explain the relative lack of even basic work about the poetic principles of Belyi's corpus, Gerald Smith speculated that difficulty - the texts' obscurity of reference and their sheer virtuosity - was one cause (but it would hardly be determinative, we might note, given the attention paid to decoding the work of Khlebnikov or, of course, Mandel'shtam). ${ }^{13} \mathrm{He}$ added that the paucity of reliable, definitive texts was a further problem. Smith was writing in the 1980s, since which time better texts have been published. ${ }^{14}$ But the textual issue he highlighted, Belyi's tendency to revise his work, has not been resolved, nor could it be easily dismissed. ${ }^{15}$ Smith may be correct in suggesting that the presence of equally plausible variants has kept even the best work from exuding the status of masterly, seemingly perfect poetry. The depth and principled formal rethinking of Belyi's late revisions are traits that are also pertinent to Mnatsakanova's poetic practice.

Belyi's extensive writings about poetry and verse theory show well the elements of his thinking that draw a poet of Mnatsakanova's temperament to him. Belyi wrote that all language is first and foremost made of sound, and, by combining sounds to form a word, the speaker or writer brings into being a new world: "the creative word creates a world." ${ }^{16}$ Belyi's idea of how language works is quite far from the metaphors of the machine or the code that have often dominated post-Saussurean linguistics and literary theory, although one can find a similar insistence that (artistic) language reaches beyond what words themselves seem to name in the theories of Walter Benjamin and Giorgio Agamben. ${ }^{17}$ And poets in other traditions have approached poetry as principally aural, for example, the American poet Susan Howe. ${ }^{18}$

13. G. S. Smith, "Bely's Poetry and Verse Theory," in John E. Malmstad, ed., Andrei Bely: Spirit of Symbolism (Ithaca, 1987), 242-47.

14. Most notably Andrei Belyi, Stikhotvoreniia $i$ poemy, ed. and introduced by A. V. Lavrov and John E. Malmstad, 2 vols. (St. Petersburg, 2006). Smith's basic point about the relative lack of scholarship about the poetry was echoed and updated in a postscript Gasparov added in 1997 to his earlier study, "Belyi-stikhoved i Belyi-stikhotvorets," 438. For a study of the intellectual environment of the poetry, rich with detail, see A. V. Lavrov, Andrei Belyi v 1900-e gody: Zhizn' i literaturnaia deiatel'nost' (Moscow, 1995).

15. See the judicious account of this history in Malmstad's introduction, "Muki slova': Ocherk istorii formirovaniia i publikatsii stikhotvornykh knig Andreia Belogo," in Belyi, Stikhotvoreniia i poemy, 1:41-73.

16. Andrei Belyi, "Magiia slov," from his book Simvolizm, excerpted in Belyi, Kritika, estetika, teoriia simvolizma, 2 vols. (Moscow, 1994), 1:231. Here, and throughout, unless otherwise noted, translations from the Russian are mine. The essay has been translated by Steven Cassedy: see Selected Essays by Andrei Bely, ed. and trans. Steven Cassedy (Berkeley, 1985).

17. Walter Benjamin, "The Work of Art in the Age of Its Technological Reproducibility," Third Version, Selected Writings (Cambridge, Mass., 2003), 4:251-83; Giorgio Agamben, Stanzas: Word and Phantasm in Western Culture, trans. Ronald L. Martinez (Minneapolis, 1993). See also Robert Kaufman, "Aura, Still,” October 99 (Winter 2002): 45-80.

18. Howe describes her work as a "vocalized wilderness format" in Souls of the Labadie Tract (New York, 2007), 17. In an interview, Howe said, "in spite of all my talk about the way the page looks ... strangely the strongest element I feel when I am writing something is acoustic." Elisabeth A. Frost and Cynthia Hogue, eds., Innovative Women Poets: An Anthology of Contemporary Poetry and Interviews (Iowa City, 2006), 161. 
Given this emphasis on what we might call, after Benjamin, the aura of words, the combination of Khlebnikov and Belyi grows more natural, especially if one takes into account Khlebnikov's beliefs in the pagan power of words and his search for a magic that inheres in the sounds themselves. ${ }^{19}$ (Belyi, son of a mathematician, also shared with Khlebnikov a fascination with mathematics, and his use of statistical measures in Simvolizm [1910] was pathbreaking). Belyi's commitment to the musicality of verse and his extensive explorations of musical form and structure - in his poetry as well as in his prose-provide a context for understanding this yearning for some semantic or cognitive capacity of words beyond their referentiality. As Gerald Janecek writes, for Belyi "the text is a musical score," and "his visual devices were intended to show how the text should be recited." ${ }^{20}$ In Ritm kak dialektika (Rhythm as dialectics, 1929), Belyi emphasized rhythmic analyses across poetic lines, which one can see as the extension of his work in the music of poetry; it also showed the effect of his absorption of the principles of anthroposophy, particularly its implicit argument about the unity of spiritual forces across disparate material.

The look of some of Belyi's late poetry is a further pertinent aspect of this legacy. He was one of the poets who first wrote poetic lines in narrow columns (stolbiki), and his experiments in verse layouts forged possibilities that were pursued in the stair-step verse of Vladimir Maiakovskii (whose fame in this regard has probably overshadowed Belyi's significance in a further way). Belyi's columns often take a regularly metricized line and break it up visually, a process that can obscure the rhythm but make more visible the internal rhymes or sound similarities; the effect was to create "vertical rather than horizontal linkings of words."21 The visual impact of Belyi's writings extends to his prose, as studies of the page layouts for his symphonies and portions of his novel Petersburg have shown. ${ }^{22}$ This merging of poetic logic with material that looks and proceeds like prose is one of Belyi's many liberating gifts for his successors.

\section{Mnatsakanova as Maker of Visual and Verbal Text}

Scholars have done important groundwork in introducing Mnatsakanova to an English-speaking audience (here Gerald Janecek's leadership has been invaluable) and to Russian readers in and beyond Russia (particu-

19. This similarity between Khlebnikov and Belyi is noted in Gerald Janecek, The Look of Russian Literature: Avant-Garde Visual Experiments, 1900-1930 (Princeton, 1984), 92.

20. Ibid., 25. In the introduction to the volume of Mnatsakanova's poetry forthcoming in Moscow, entitled "Dver' v novoe iskusstvo," Iurii Orlitskii also mentions Belyi's musical writing as an antecedent for her work.

21. Herbert Eagle, "Typographical Devices in the Poetry of Andrey Bely," in Gerald Janecek, ed., Andrey Bely: A Critical Review (Lexington, 1978), 71. Eagle goes on to comment, based on his reading of the two-part poem "Zolotoe runo" (The golden fleece) that "the diffusion of sound play throughout the verse rather than its concentration in the final end rhyme reduces the semantic dominance of that final rhyme" (76); "Bely's typography does foreground the intonational level of the poem's sound, creating an auxiliary rhythmic pattern which competes with the meter for dominance" (77).

22. See especially Janecek, The Look of Russian Literature, 25-44. 
larly in the Moscow journal Novoe literaturnoe obozrenie).$^{23}$ Let me rehearse only the facts of her life and work that are pertinent to my argument about her cultural heritage and her work in visual poetry. A poet and visual artist as well as an accomplished translator to and from German, Mnatsakanova was trained as a musicologist in Moscow; her profound musical temperament is surely one element of her deep affinity for the work of Belyi. She lives in Vienna, having emigrated from Moscow in 1975, and teaches Russian literature at the university there. In Vienna, she published a number of books of visual poetry, translations, and essays, at her own expense, in tiny print runs, with no distributor. ${ }^{24}$ Many of these volumes carry the name Elisabeth Netzkowa: once in Vienna, she adopted this surname, which is easier for her piano students to pronounce, although her books usually also carry Mnatsakanova or, more often, Mnatsakanian, on the title page. This multiplicity of self-naming encodes the poet's own facility in moving between languages, principally German and Russian, but also Latin and Italian, and the titles of her poems draw on these languages, too.

Two volumes of her poems have appeared in Russia; a third is in press through Novoe literaturnoe obozrenie in Moscow and will make the poet's work more broadly accessible, at last. ${ }^{25}$ The second of the Russian books, Arcadia (2004), was assembled by the excellent Moscow poet and physicist Vladimir Aristov (whose name should be added to the list of poets appearing in a full-fledged study of the Khlebnikov effect). In December 2004, Mnatsakanova was awarded the Andrei Belyi Prize; in 2006, she visited St. Petersburg as the guest of the artist Mikhail Shemiakin. ${ }^{26}$ He mounted an

23. Gerald Janecek, "Elizaveta Mnatsakanova," in Christine D. Tomei, ed., Russian Women Writers, 2 vols. (New York, 1999), 2:1377-92; Janecek, "Paronomastic and Musical Techniques in Mnacakanova's Rekviem," Slavic and East European Journal 31, no. 2 (1987): 202-19. The first Russian attention to the poetry came in the 1990s: Vadim Rudnev, "Stikhoslozhenie Elizavety Mnatsakanovoi," and Aleksandr Sekatskii, "Poema i mantra," both in Mitin zhurnal, nos. 45-46 (May-August 1992): 115-26, and 127-37. NLO first published Mnatsakanova's work in 1995, one page of calligraphy entitled "Variatsii na temu N. S. Artmann," with a prefatory note by Sergei Biriukov, "Zrimoe zvuchanie," NLO, no. 16 (1995): 186-88. More recently, NLO made available both Janecek's work and some previously unpublished texts by the poet, as well as a republished and corrected version of her poem Rekviem, which had appeared in Paris in the 1970s. See E. A. Mnatsakanova, "Osen' v lazarete nevinnykh sester: Rekviem v semi chastiakh," and Gerald Janecek, "Rekviem' Elizavety Mnatsakanovoi," both in NLO, no. 62 (2003): 253-71 and 272-79; E. A. Mnatsakanova and N. Khardzhiev, “Prichastnost' k sile bukv' (perepiska 1981-1993 godov)," NLO, no. 79 (2006): 248-66.

24. Mnatsakanova's self-published books in Vienna include Beim tode zugast / U smerti v gostiakh (1986); Das Buch Sabeth: Kniga v piati chastiakh (1988); Metamorphosen: 20 Veränderungen einer vierzeiligen Strophe und Finale (1988); Das Hohelied: Bilderzyklus zu dem Gedichtband Das Buch Sabeth (1990). In addition, she has assembled a book of her criticism: Vorlesungen zur russischen Literatur (2001).

25. Mnatsakanova, Vita breve: Iz piati knig, izbrannaia lirika 1965-1994 (Perm', 1994); Arcadia: Izbrannye raboty 1972-2002 (Moscow, 2004).

26. On the events in Petersburg, see the short announcement posted at www.russkyformat.ru/sections/russian_culture/osen_v_lazarete/view (last accessed 23 May 2008). Shemiakin was also the first to publish her great poem "Osen' v lazarete nevinnykh 
exhibit of her work and an evening during which her poetry was read by the actor Leonid Mozgovoi; both drew enormous crowds.

This belated attention from Russians has brought Mnatsakanova great pleasure, but her long geographic separation from a reading public became a significant and lasting fact in her work. She produces a striking effect of distance in her writings, and that separateness seems at times modeled on Khlebnikov's cultivation of solitude. (But, as I suggest below, there are formal, visual, and rhetorical features of her work that mitigate against such extreme solitude.) Among poets, Khlebnikov has played the most visible role in Mnatsakanova's aesthetic criticism and essayistic prose. She translated Khlebnikov into German and worked on a series of graphic designs to accompany his texts (in 1980). ${ }^{27}$ In her writings, she has noted the distances he created and endured. In her first essay about him, a lengthy piece that appeared in the Paris journal Sintaksis in 1983, she prefaced her detailed analysis of his poetry with toneless statements about how little his contemporaries knew his work: "Khlebnikov was almost completely unpublished, either at the start of his career or at the end," she writes; the isolation around the poet built a "wall of silence' around him that still stands." ${ }^{28}$ In her second essay, she finds his poetry to be surrounded by a solid "aura of purity and chasteness," while she sees Khlebnikov himself as on the sidelines, a kind of observer from elsewhere ("etot chelovek byl storonnim - ili po-tu-storonnim - nabliudatelem") ${ }^{29}$

Both of these comments, about the ways in which poets isolate themselves within walls of their own building and the vantage point created when one stands on the sidelines, describe the work of Mnatsakanova herself, particularly in the 1980s and early 1990s. She has written "my life now is surrounded by silence. Probably this resides in my very nature: to be silent, and silently to do my work." ${ }^{30}$ Although her admiration of Khlebnikov is clear, Mnatsakanova would probably object to this discovery of a likeness. She has resisted any suggestion that she was influenced by him. ${ }^{31}$ And yet she, too, is the kind of observer from the periphery she

sester: Rekviem v semi chastiakh" (Autumn in the lazaretto of innocent sisters: A requiem in seven parts) in Apollon-77 (Paris, 1977), 173-83, accompanied by his own striking illustration.

27. In 1980, when there were exhibits of her work in Vienna, Bregents, and Paris, she worked on a series of graphic works inspired by the writings of Khlebnikov, Aleksandr Pushkin, and Martin Luther. See Mnatsakanova, Arcadia, 192.

28. Mnatsakanova, "Khlebnikov: Predel i bespredel'naia muzyka slova," Sintaksis, no. 11 (1983): 102. This essay is accompanied by calligraphic illustrations by the poet, using Khlebnikov's poetry as the basis for the calligraphy. The essay is the subject of Brian Reed, "Locating Zaum: Mnatsakanova on Khlebnikov," Jacket 27 (April 2005) at jacketmagazine .com/27/reed.html (last accessed 23 May 2008), which also places Mnatsakanova's reaction to Khlebnikov's theories of language into larger questions of avant-garde poetic production.

29. Mnatsakanova, Arcadia, 117. Russian.

30. Elizaveta Mnatsakanova, letter to the author, 15 November 2004; original in

31. In an interview on BBC, aired on 15 November 1991, this is said with particular force. Mnatsakanova concedes that she learned from Khlebnikov to despise imitations 
found in Khlebnikov. In one of her tersest statements of that paradox, Mnatsakanova has said of herself, "I have always tried to live and especially to work outside of known traditions." ${ }^{2}$

Mnatsakanova has not written in such detail about Belyi, although her admiration for him is clear. On receiving the prestigious Petersburg prize given in his name, she reread a number of Belyi's books, mostly his prose, and declared that this return to his writings, prompted by the award, was for her its greatest gift. She wrote, "The force of his thought made an especially strong impression on me. He was after all educated as a mathematician, a calling he inherited from his father. Based on the level of his thinking, he was very far ahead of ALL of his contemporaries. [. . . What a tragic fate he had. If there were more time, I would write something extensive about him, but I can't do it." 33

In her acceptance speech for the award, Mnatsakanova cites two lines from his poem "Druz'iam" (To my friends, 1907), without identifying the poet ${ }^{34}$ the poem's larger insistence that the poet does not die, that the departed will always return, alludes to the central theme of Mnatsakanova's "Das Hohelied," discussed below. The acceptance speech itself draws on some of Belyi's key ideas, among them: an emphasis on the role of thought as a measure of time in poetry; an assertion that poetry creates other forms of time and space; and an invocation of "the magic of words" (magiia slov). ${ }^{35}$ Mnatsakanova expounds on the fantasy of a place where linguistic signs would have the magical force to cross temporal and spatial boundaries. The speech also quotes from the introduction to Belyi's great poem "Pervoe svidanie" (First encounter, 1921), a passage into which Mnatsakanova inserts two lines of her own; the quotation includes his phrase "the magic of words." She ends by freely citing the words of one she calls "the Mathematician, who knows the value of the Simility of an Unassimilable Sequence and the Eternal Iterability of the Unrepeatable" (Skhodimost' Neskhodimogo Riada i Beskonechnaia Povtoriaemost' Nepovtorimogo).$^{36}$ I have weakly replicated the use of neologism in this

and borrowings that essentially become forms of plagiarism. One can compare a statement written in German that appears on the back cover of Das Buch Sabeth where the poet insists that the poems have no models, indeed that every poet must create an individual and original sense of form.

32. Mnatsakanova, "O prostranstvakh vremen," published on-line at magazines.russ .ru/project/bely/mnatsakanova_talk.html (last accessed 23 May 2008).

33. Elizaveta Mnatsakanova, letter to the author, 22 February 2005; original in Russian. Mnatsakanova errs in saying that Belyi was educated as a mathematician-he was trained in the natural sciences-but her assertion valuably conveys her impression of his turn of mind.

34. Belyi, Stikhotvoreniia i poemy, 1:264. This is one of the poems Belyi produced in a stolbik version as well: compare 2:335. Mnatsakanova cites the better-known text with longer lines: "Dumoi veka izmeril, / A zhizn' prozhit' ne sumel." Belyi regarded the poem as an epitaph for himself: see Andrei Belyi, Stikhotvoreniia i poemy (Moscow-Leningrad, 1966), 600 .

35. The repeated epithet "flying" (letaiushchii) for the word poet is also probably an echo of the early Kotik Letaev by Belyi.

36. Mnatsakanova's writings often use bold lettering (as here) or all-capitalized words, or italic script, and in all instances this has been preserved in quoting here. 
phrase, the better to foreground yet another device prominent in Belyi's (and Khlebnikov's) work, word creation. But the attention paid to repetition and to an idea of an utterance whose shape, sequence, and tone cannot be repeated also owes a great deal to Belyi's central argument in Rhythm as Dialectic. Repetition, as we shall see, is the key rhetorical feature of her work.

Mnatsakanova's poetry, like Belyi's, is more musical than Khlebnikov's (her training in music and her continued passion for musical performance are important), but she is like both poets in her fascination with the way words sound and in her use of poetic texts to explore deeply phonological and morphological connections. Words break apart, recombine, and seem almost to move across the page before a reader's eyes; in that movement, they enact journeys toward and away from one another. These metaphors could have been drawn from Belyi's work, for example, from "The First Encounter," where the sound orchestration is extremely rich, or from any of Khlebnikov's poems where sounds recombine and repeat as if they were magic spells.

Amid all this aural movement, Mnatsakanova perhaps unexpectedly finds ways to cultivate a strange silence. The silences are felt in the blank spaces between poems or words, like the rests that give rhythm to musical composition. ${ }^{37}$ Something of this pause for silence is found in Belyi's work, particularly his third volume of poetry, Urna (The urn, 1909), with its debt to the poetics of Evgenii Baratynskii. ${ }^{38}$ Mnatsakanova's poetry creates a sound environment in which the listener is caught in a seemingly endless present: sounds repeat and recombine, and words shift as speech acts from imprecations to affirmation, from plea to prediction. In that appeal to the imagination, Mnatsakanova asks readers to join her in an experience of the senses and of the mind's capacity to bend language as if it were clay to be sculpted.

What senses exactly does this act of linguistic imagining involve? In particular, how does the appeal to both eye and ear work? The more intensely visual the poetic text on the page, the less plausible it might seem as a script for an oral performance-a division between what Mikhail Gasparov called "verse for the ear and verse for the eye." 39 Sound poets usually emphasize musical expression or sound play, whereas visual poets innovate in terms of the look of words, letters, and images on the page. ${ }^{40}$ Yet Mnatsakanova's poetry insists on both visual and aural

37. For a substantial analysis of Mnatsakanova's reliance on structuring principles from music, see Janecek, "Paronomastic and Musical Techniques."

38. On that connection, see Lavrov's introduction, "Ritm i smysl: Zametki o poeticheskom tvorchestve Andreia Belogo," in Belyi, Stikhotvoreniia i poemy (2006 ed.), 1:30-32.

39. Mikhail Gasparov, A History of European Versification, trans. G. S. Smith and Marina Tarlinskaja, ed. G. S. Smith with Leofranc Holford-Strevens (Oxford, 1996), 288-92. Gasparov mentions Belyi's late work in passing as an example of poetry for the eye, but these pages deal principally with classical, Renaissance, and modern texts from outside the Russian tradition.

40. For a brief account of the range from purely graphic sign to near-musical notation, see V. Kulakov, "Vizual'nost' v sovremennoi poezii," NLO, no. 15 (1995): $253-54$. 
intensity. ${ }^{41}$ Visual symmetries, designs, patterns, and complementary images find rewarding expression, but without any simplification of sound orchestration. In this she is Belyi's heir, I would suggest. ${ }^{42}$ Sight comes to have a constituent relationship to sound, to have the capacity to determine its pitch, tone, and intensity. The imaginative act that the reader is invited to perform, then, is an unusually interactive experience of sight with sound, requiring an ability to process information from both eye and ear and to move back and forth between these two sites for sensory input. If one switches here to a more scientific register, it is perhaps because cognitive scientists have led the way in explaining how the brain accepts stimulus from different sense organs. Rather than the "common romance of sensory immediacy" as a way to understand the mind's absorption of aesthetic material, these theorists argue for a model of mental processing that permits the interaction of multiple stimuli and indeed studies what happens-what sites of pleasure are stroked, what tensions arise in the mind-when the stimuli interact. ${ }^{43}$

Repetition is the rhetorical device that makes this interaction possible. It is a key trope in Mnatsakanova's visual poetry, producing echoes of sounds, letters, shapes, colors, phrases, individual words, and thematic motifs. All automatic response to language - all assurance that words are simply referential - slows. This retardation is more radical than the device as described by the formalists, and it has a measure of what they called defamiliarization. Decomposition of words and sounds, combined with the enormous amount of repetition, breaks words down into their constituent parts. These sounds can coalesce into a wave that washes over the reader or listener and leaves behind an echo of repeating sound that is thick emotion. The look of the words on the page can spread out with spaces between the words, words as columns, pieces of words marching down the page, and even angular handwritten text around, beneath, or across the typographical page. The words themselves can vanish, as in one album page that has only a vivid blue border at the right. One way that the poet makes the sounds' disappearance palpable is to show us the stress patterns left behind by the absent words. ${ }^{4}$

41. This mix of sound with sight is emphasized as well in Biriukov, "Zrimoe zvuchanie."

42. Recall Belyi's widow's recollection of the moments when he would present variant layouts of a poem and ask that she compare them to decide which would sound the best. Klavdiia Bugaeva, "Stikhi ob Andree Belom," Novyi zhurnal, no. 102 (1971): 107-8, quoted by Eagle, "Typographical Devices," 83.

43. The quotation comes from Monson, "Hearing, Seeing, and Perceptual Agency," S49. For pertinent cognitive theorists, see Mark H. Johnson, ed., Brain Development and Cognition: A Reader (Cambridge, Mass., 1993); Gerald M. Edelman, Wider than the Sky: The Phenomenal Gift of Consciousness (New Haven, 2004); Stephen Kosslyn and Olivier Koenig, Wet Mind: The New Cognitive Neuroscience (New York, 1992).

44. For one example of these stress marks, see "Krugovaia pechal" in Das Buch Sabeth, 70 ; also, in this part of the poem, one frequently senses the phrase, "Utoli moia pechali," which is present as the title of this part of the poem but written in poetic lines only as word fragments. Gerald Janecek has noted that the missing words were excised because they 
The disappearance of language is pushed to its extreme in Mnatsakanova's art work. In a series of drawings (separate from her poetry books) done in colored pencil, she has represented the Swiss landscape of lakes and mountains around Davos, Switzerland. ${ }^{45}$ The images show a mixed blue palette, with visible pencil strokes and an openness of form. Some conjure the hazy shape of the letter $E$, the poet's "trademark" (marka), as she has called it, for its capacity to signify her first name. The central, large $E$ is referential as well as pure shape. It seems an absorbed and absorbing eye, opening toward the right side of the picture in one image as if expecting some movement or change, or perhaps simply observing a far-off and hazy distance. For Mnatsakanova, what is most valuable is not what is near at hand, but what is far from the seeing eye, and this hypervaluation of that which seems unattainable comports nicely with the poetic system championed by the symbolist Belyi. Mnatsakanova's poems transpose a fascination with what is barely glimpsed into a play with sound that holds the reader's attention.

In her books, the letter $E$ becomes a mark of ownership, a signature that is seen on the final page in some books and as a design element in calligraphic pages. Examples include the border used on the inside cover of Arcadia (figure 1). Some images recast the calligraphic borders into a rippling line of large $E$-like loops that demarcate one side of the image. The border may function as a boundary, thickening the edge of the page as if to separate its verbal content from the words of the world. That thickened wall is one way to understand the asymmetrical bordering on the title page of Metamorphosen (figure 2). The borders differ in thickness and thus in the impression they make on the eye, and various allegories are suggested: some borders-for instance, the border between letters and images - are less formidable than others. ${ }^{46} \mathrm{~A}$ comment by the American poet Charles Bernstein about the work of Susan Howe is surprisingly apt in this case: "Look at a page as border marking the intersection of sight and words." ${ }^{47}$ The border between poet and reader is also, I will ar-

were too private or important. See Janecek, "Elizaveta Mnatsakanova," 1382. The disappearance of language in Russian and Ukrainian avant-garde poetry has been studied by Tatiana Nazarenko in "Words Abandoned: Pictograms and Ideograms in Contemporary Russian Visual Poetry," Canadian-American Slavic Studies 36, no. 4 (2002): 447-69; and Nazarenko, "Re-Thinking the Value of the Linguistic and Non-Linguistic Sign: Russian Visual Poetry without Verbal Components," Slavic and East European Journal 47, no. 3 (2003): $393-421$.

45. Four copies of these images, made by the poet, are held at Houghton Library, Harvard University. See also Mnatsakanova's postcards from Davos, seven of which are in Houghton; and the smaller Davos landscape series (originals in the Albertina, copies made by the poet of eleven images in Houghton).

46. The book artist and scholar Johanna Drucker has perhaps done most to show us the range of ways in which artists and writers have used alphabet letters. See her Alphabetic Labyrinth: The Letters in History and Imagination (London, 1995); and Figuring the Word: Essays on Books, Writing, and Visual Poetics (New York, 1998).

47. Charles Bernstein, “Passed by Examination': Paragraphs for Susan Howe,” My Way: Speeches and Poems (Chicago, 1999), 100. Howe's work is firmly anchored in American history, including American religious history, which marks an important difference from 


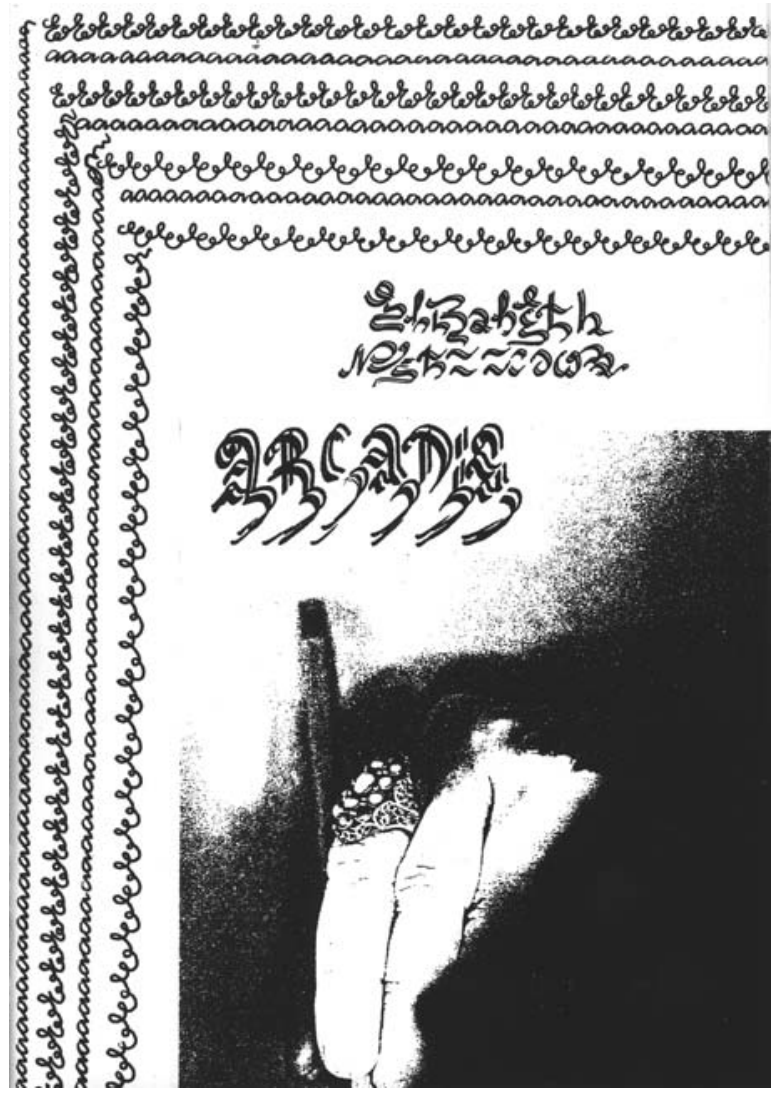

Figure 1. Elisabeth Netzkowa Mnatsakanova, Arcadia, inside front cover. Courtesy Elizaveta Mnatsakanova.

gue, more of a permeable membrane than any sort of forbidding boundary zone.

The vertical borders do another important kind of work in this poetry, training the eye to move down the page as easily as it moves, from long habit, horizontally across lines of writing. Belyi's poetry implicitly instructed his readers to learn this ocular flexibility when he made rhymes or sight similarities down the page. Gerald Janecek has shown that Belyi could use the long dash of punctuation in a similar manner. ${ }^{48}$ Mnatsakanova has learned extremely well from her predecessors, then, as can perhaps best be shown by looking more carefully now at one of her long poems.

Mnatsakanova's thematic orientations. But there are strong affinities in their conceptions of how visual signs make up poems. Howe's visual poetry can depend on the decomposition of words, sentences, and strophes, as we find in Mnatsakanova's work. See, for example, Howe's poem “Thorow," Singularities (Middletown, 1990), 39-60, as well as the final section of Souls of the Labadie Tract.

48. Janecek, The Look of Russian Literature, 47-55. 


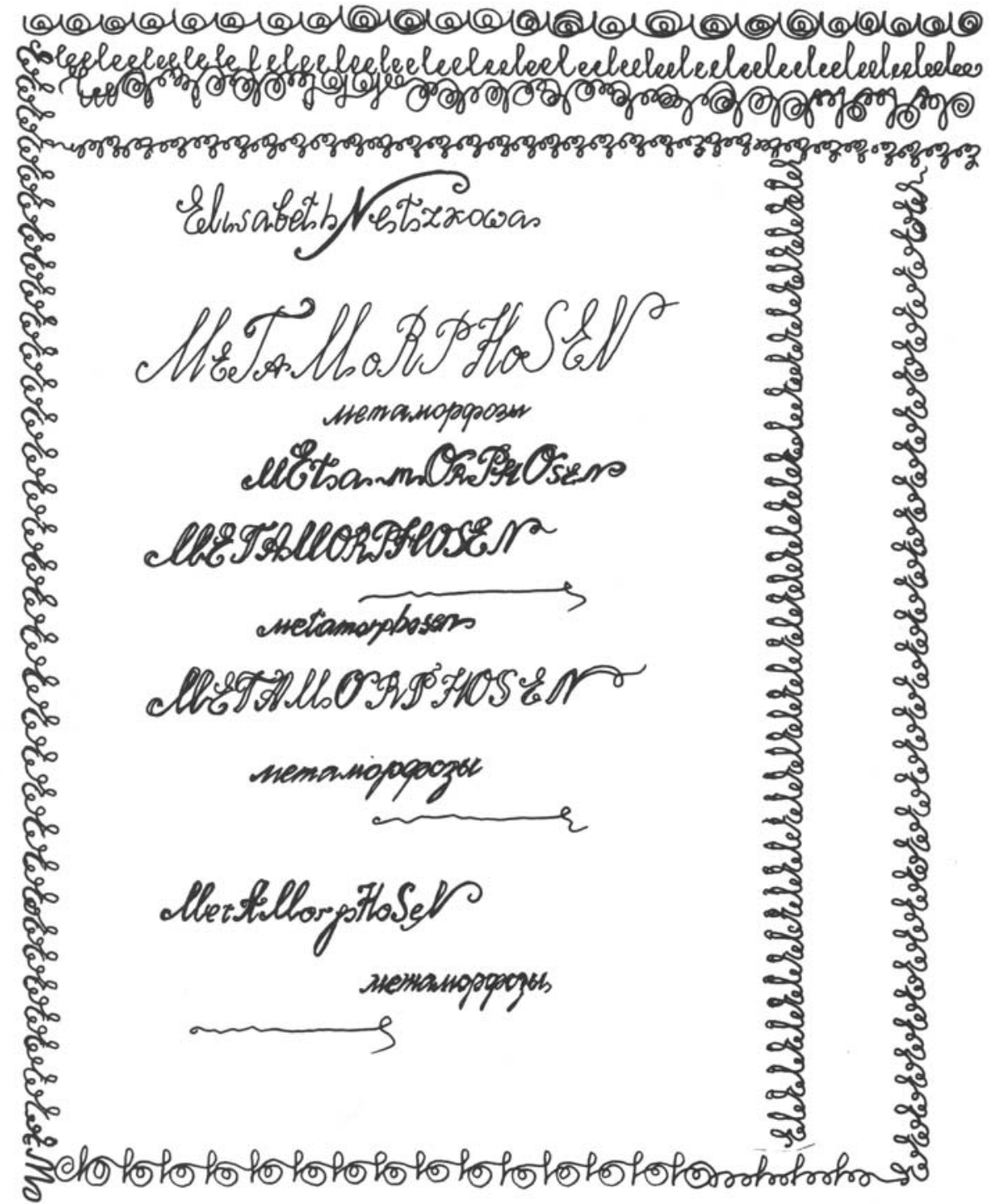

Figure 2. Elisabeth Netzkowa (Mnatsakanjan), Metamorphosen, handwritten title page. Courtesy Elizaveta Mnatsakanova.

\section{"Das Hohelied" as First Meeting and Last Farewell}

Mnatsakanova has made several albums from "Das Hohelied" (Song of Songs), which forms the fifth and final section of Das Buch Sabeth (The Sabeth book; the German-language title, as is true elsewhere in Mnatsakanova's work, designates poetry whose principal language is Russian). A small number of one-of-a-kind albums for "Das Hohelied" exist, and the poet also produced an album in multiple, printed 
copies. ${ }^{49}$ In some copies of Das Buch Sabeth, the poet included a final section of color and black-and-white images, as well. In Das Buch Sabeth, even in entirely typeset versions, the visual style shows much variety. Page layouts can preserve the contrast of a right-hand column of writing that sets off a "central" text; ${ }^{50}$ several parallel columns of single words can be presented; or words can spread out all over a page in small asymmetrical groups. Some columns of words can angle off to break the barriers of words that otherwise line up vertically. In this usage of both columns of words and diagonally placed sequences, Mnatsakanova follows the example of Belyi's ballad "Shut" (The buffoon, 1911), although her variety of positions for words on the page far exceeds his. ${ }^{51}$

The angled sequences can appear in handwriting over a typeset text, or as further typeset sequences, in either case creating a dynamic challenge to the usual vertical-horizontal axis of poetic texts. In a particularly vivid instance of this dynamic layout (figure 3, from part 3 of Das Buch Sabeth), the mix of printing and handwriting, and of perpendicular with angled lines, finds a further contrast in the use of two languages, German layered onto Russian; a mix of languages is not unusual in Mnatsakanova's work. ${ }^{52}$ In this case, the German words bespeak a prayer to the heavenly Virgin layered over the incantatory words of the poem. ${ }^{53}$

Das Buch Sabeth is a love poem, and "Das Hohelied," its fifth and final

49. One of these one-of-a-kind albums, which I have been able to study closely, is held at Houghton Library, Harvard University. Others are held at the Albertina Museum, Vienna; at the Paul-Klee-Stiftung in Berne; and in the poet's personal collection.

50. Gerald Janecek has observed that this format is inspired by a musical form: "Das Hohelied" "is particularly interesting in being in the unprecedented form of a musical passacaglia, in which a column of italicized words appears on the right or left to represent the repeating organ pedal line of the traditional musical form, while the center of the page provides variations consisting of a flux of everyday phrases. In Mnatsakanova's version of the form, the columns representing the pedal line do not remain constant, but change and evolve as well." See Janecek, "Elizaveta Mnatsakanova," 1381-82.

51. This unique (for that time) mix of diagonally placed lines with horizontal columns has been studied by Gasparov: "Shut' A. Belogo i poetika graficheskoi kompozitsii," Izbrannye trudy, 3:439-48.

52. Other poems in the third part feature this use of handwriting angled over columns of printed words; these are among the pages that would pose the greatest challenge to oral performance. The columns (also seen in some of the poems in the first part) are like the stolbiki pioneered by Belyi but here multipled in several columns across the page.

53. Latin, the language of Catholic ritual, also plays an important role in Das Buch Sabeth. This is signaled on the first page of the volume, before the first poems begin. The lines begin:

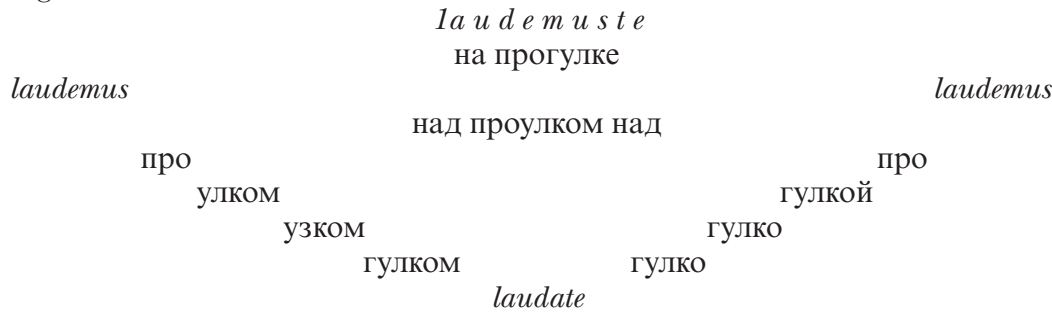

In another large-scale poem, El'moli (in press), Mnatsakanova produces a similar effect with Italian and Latin. 


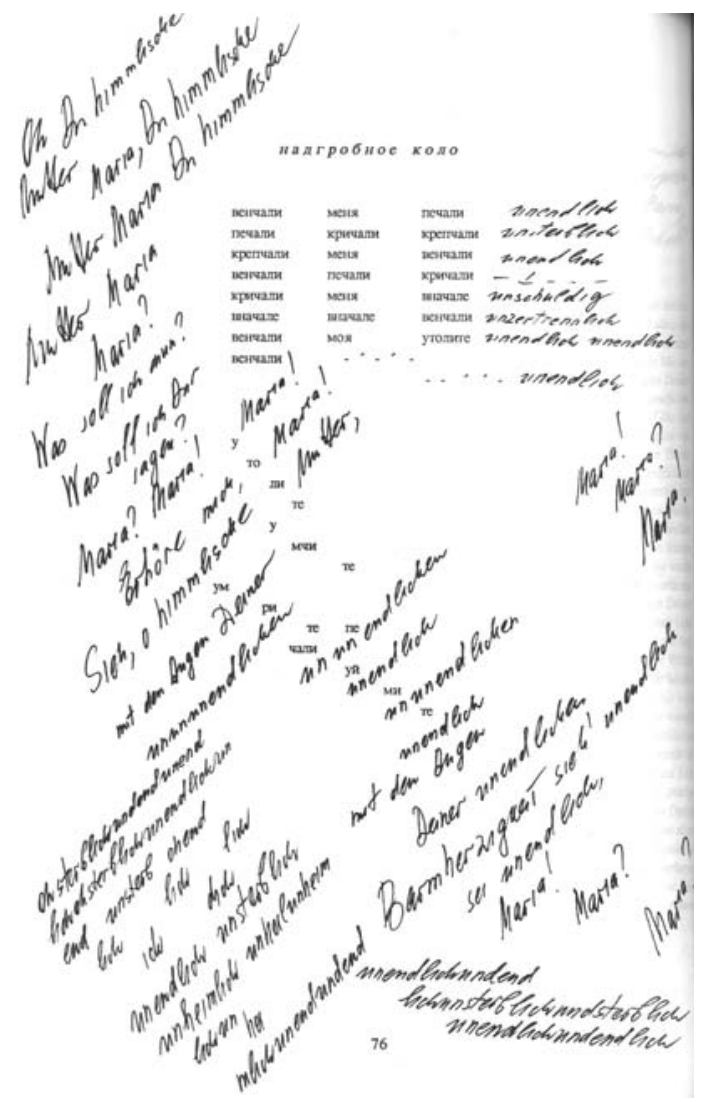

Figure 3. Elisabeth Netzkowa (Mnatsakanjan), Das Buch Sabeth, second page of poem No. 5 in Part 3, "Utoli moia pechali" Lamenti, 76. Courtesy Elizaveta Mnatsakanova.

part, takes its title from the short book of the Old Testament in which King Solomon sings of love and its raptures. He writes "Set me as a seal upon thine heart, as a seal upon thine arm: for love is strong as death" (Song of Solomon 8:6), and "Das Hohelied" is poised at that balance between love and death. ${ }^{54}$ The poet has said that the poem memorializes a man she loved very much, someone whose subsequent death was a tragedy for her. Nothing specific about this man, including his name, is mentioned. The man's presence is ciphered as a date, 12 March 1972. Those numbers and the name of the month are used in many ways in the poem, allowing the poet to explore the place-holding and symbolic value of numbers.

54. The biblical verse elsewhere recounts a tale of loss that feels similar to "Das Hohelied": "I opened to my beloved; but my beloved had withdrawn himself, and was gone: my soul failed when he spake: I sought him, but I could not find him; I called, but he gave me no answer. The watchmen that went about the city found me, they smote me, they wounded me; the keepers of the walls took away my veil from me. I charge you, O daughters of Jerusalem, if ye find my beloved, that ye tell him, that I am sick of love." Song of Solomon 5:6-8. 
Variations appear as datelines in the early poems in Das Buch Sabeth. ${ }^{55}$ The book's final page, with its emphatic assertion "End of the book end of the book end of the book" (Konets knigi konets knigi konets knigi), has a complex dateline: the first reads 12 March 1972-12 May 1972 Moscow; the second, 12 September 1987 Vienna. ${ }^{56}$ By means of subtle changes, the poet turns the dates into temporal signposts that endow the poem with an aura of fated repetition. The variations both stabilize the numerical precision of the original date and open it out to other days that will become its commemoration. The constituent features of the date-month, day, digits in the numbering of day or year - are treated like the elements of words: the numbers are like letters, ready for transposition, reconfiguring, and metamorphosis.

The poet has explained why 12 March 1972 is significant:

The whole book grew out of this day-12 March. [. . .] In the morning of 12 March 1972, I began to write, stopping only that afternoon, when I put the period after the last word of the poem. Or, rather, there was no period, also no last word, there were only two syllables of the word continues [prodolzhaetsia] because this book did not end, it ends only with the death of the author. ${ }^{57}$

Timing gives rise to lexical elements in the poem, for example, the reference to the Ides of March in part 1, "Laudes," but time all but disappears by the last part of the poem, "Das Hohelied." The nouns grow starkly abstract: "sign," "death," love" (znak, smert', liubov'). Other words that resound in the poem are "familiar," "immortal," "mortal," "in two," "cut," "forever" (znakomyi, bessmertnye, smertel'no, nadvoe, razrezany, vvek and vechno) and forms of the pronoun "you" (ty, tebia, toboi), which appears as part of a fractured word, or as a remnant from a demolished pairing. The epithet znakomyi is shortened to znak, marking the poem's self-consciousness as a receptacle for signs. We note the indexical nature of all the signs in the poem, but also the expansive range of what signs can do here.

Words in "Das Hohelied" float up from the page as if in rapture, they sag below the line in lament, they spread far from one another as if in flight, they run on in endless chains that bind together sound and meaning. Always the poet questions how well we can rationally know these signs. Pieces of a word recombine, prefixes come a line early as if part of an earlier word, and new letter combinations are created by these transposed

55. Several, including the first poem, in which the two lovers first meet, are dated 12 March 1972, others vary the year (12 March 1974 or 1984), the month (12 September 1985 or 1987), or the day and year (14 March 1973, 14 March 1984).

56. As my teacher Omry Ronen used to say, with regard to the dating of Anna Akhmatova's poems, sometimes the dateline is the last line of poetic text. Mnatsakanova's datelines also provide information about the genealogy of the text, and their very presence suggests that the poem is anchored in an experience that can be dated. The poet has also given an account of the generation of Das Buch Sabeth in Mnatsakanova, Arcadia, 183.

57. Elizaveta Mnatsakanova, letter to the author, 4 December 2004; original in Russian. I have corrected a small mistake in the poet's letter, where she wrote that she began the poem the evening (vecher) of 12 March. Later in the letter, and in other phone conversations with me, she has said that the poem was begun at 8:00 in the morning. 


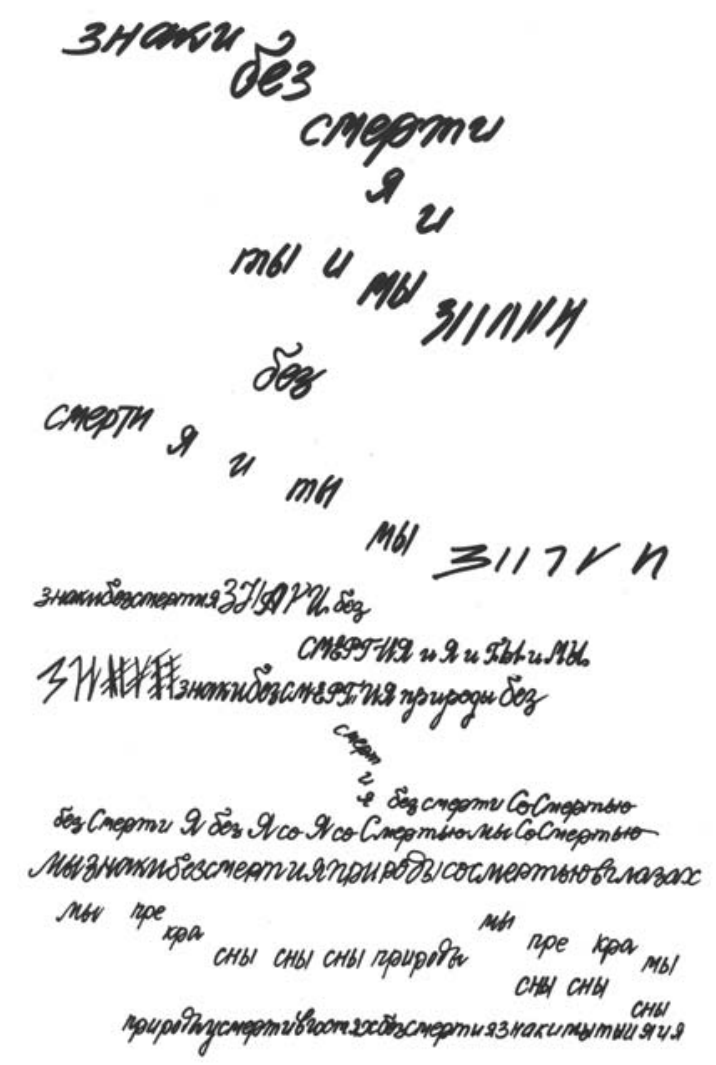

Figure 4. Elisabeth Netzkowa (Mnatsakanjan), Das Buch Sabeth, unpaginated image; also found in Elisabeth Netzkowa (Mnatsakanjan), Das Hohelied: Bilderzyklus zum 5. Teil-Finale-des Gedichtbandes DAS BUCH SABETH, unpaginated. Courtesy Elizaveta Mnatsakanova.

verbal elements. Some portions of words and some letters are reduced to indecipherable marks on a page. For example, in "Das Hohelied," there is a striking image of the word znaki (figure 4), written so that in spots it reads as the past tense verb, znali, the lines of its letters shown disappearing or twisting as if the word itself were shifting. By assembling letters to represent both words, the poet establishes a relationship between signs and knowledge: she emphasizes the fleeting nature of knowledge, in fact, as graphic elements of the verbal signs seem to disappear on the page. What is known in the poem are signs of immortality (znaki bessmertiia), but knowledge wavers because the letters seem almost to disobey the poet.

Mnatsakanova has described a moment in the act of composition that names this act of disobedience a form of independence:

The SIGNS THAT ARE LETTERS, the DESIGNS OF THE LETTERS at times, when the Author is caught up in admiring the beauty of their lines 
and the rich possibilities of combinations among these lines, will acquire a free-standing independence,

that is, they begin to live their own lives, they carry on a life of their own. ${ }^{58}$

She may remind readers of Lev Tolstoi's famous claim that his Natasha Rostova had gotten married, to his surprise. But the independence of fictional characters seems more of an authorial topos than this poet's demonstration that letters have an artistic value, quite apart from their capacity to signify sounds within a word.

How ironic, then, that the letters acquire life - an event that the poem refers to by using versions of the word rozhden - in a context of incessant reference to death. The resonant phrase "a guest of death" ( $u$ smerti $v$ gostiakh) occurs in this part of the poem, in some passages alternating with the phrase "gazing at death" ( $u$ smerti v glazakh). ${ }^{59}$ These forms of birth, then, have been made possible by staring at death, just as the poem's affirmation that love endures rests on moments of loss and separation. Death inhabits Mnatsakanova's poetry much more than that of any of her forebears, in fact: it unifies all her major texts, bringing both creative energy and the threat of impending quiescence. This thematic repetition works in concord with the formal, visual, and aural repetitions that organize the poetry.

\section{Repetition as Sense Experience}

The same phrases, sounds, and words echo across Mnatsakanova's writings: everything she has written since she began making her albums is built around repetition. The repetitions can be alliterative, paronomastic, or morphological. A column of adverbs, for example, can reiterate one group of sounds and serve a single grammatical function; or, declined pronouns (sebia tebia menia sebia in a line from "Das Hohelied," see figure 5) can provide semantic alternatives. Repetition organizes many of the visual images, too, as in the chain of the letter $E$, the essential iconic element in the poet's handwritten borders (see figures 1,2).

Among the phrases that the poet repeats in "Das Hohelied" are two that draw attention to the human experience of repetition: "love continues" (liubov' prodolzhaetsia) balanced by the rattle of death, "we are ceasing" (my prekrashchaemsia; see figures 5, 6). The theme of death, which is explicitly verbalized in earlier parts of Das Buch Sabeth, here emerges from the way the poet deploys letters on this album page: "prekrashchaemsia" becomes "prekrasny," the last syllable of which, "sny," in turn produces forms of smert' (death) as seen at the bottom of the page (see figure 5).

58. Mnatsakanova, "Slovo o slovakh" (typescript, dated 30 December 2005), 5. This is the speech Mnatsakanova sent to Moscow to mark the publication of Arcadia. Typeface choices by the author are preserved here, as is the line break.

59. Mnatsakanova made several albums for Beim Tode Zugast / U smertiv gostiakh, based on the published text (Vienna, 1986). Two of these are held in Houghton Library, Harvard University. The poet says some albums for this poem appeared as early as 1975; see Mnatsakanova, Arcadia, 191. 


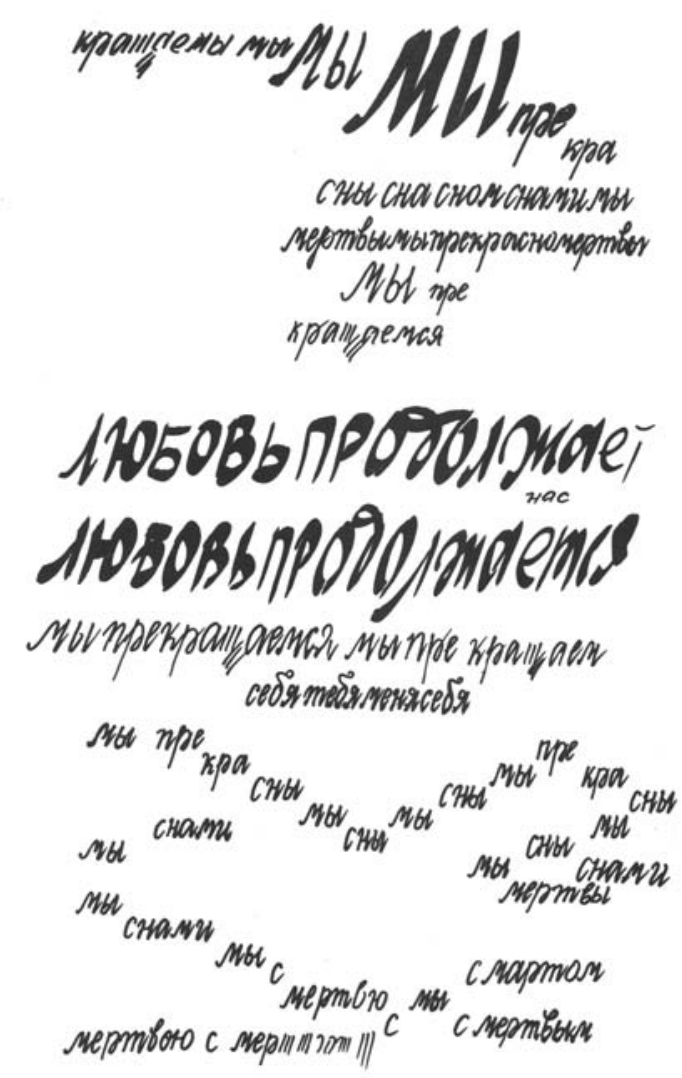

Figure 5. Elisabeth Netzkowa (Mnatsakanjan), Das Buch Sabeth, unpaginated image; also found in Elisabeth Netzkowa (Mnatsakanjan), Das Hohelied: Bilderzyklus zum 5. Teil-Finaledes Gedichtbandes DAS BUCH SABETH, unpaginated. Courtesy Elizaveta Mnatsakanova.

The forms merge and mingle and, in the last line, fade into parallel vertical lines that leave the letters unspecified, as was seen in the words znaki and znali. In this case, the letters' fluidity signals the ubiquity of the phenomenon they signify. Death keeps returning as a theme and as a visual element. Its capacity to stop life seems diminished by its constant presence in the life of the living. Death has no suddenness, as if it does not constitute an interruption. Even the statement that death is present, "we are ceasing," occurs in the present tense, denoting a process without endpoints rather than a clearly bounded event.

Love continues, the poet says over and over again, using the last poem and the last page of the poem to build a column of words, not at the right margin of the page this time, but horizontally at the bottom of the page (figure 6). This emphatic gesture of closure resists finality, because it seals together words and letters where nothing can cease the motion of continuing. Above those three gradually elongating lines, the poet makes 


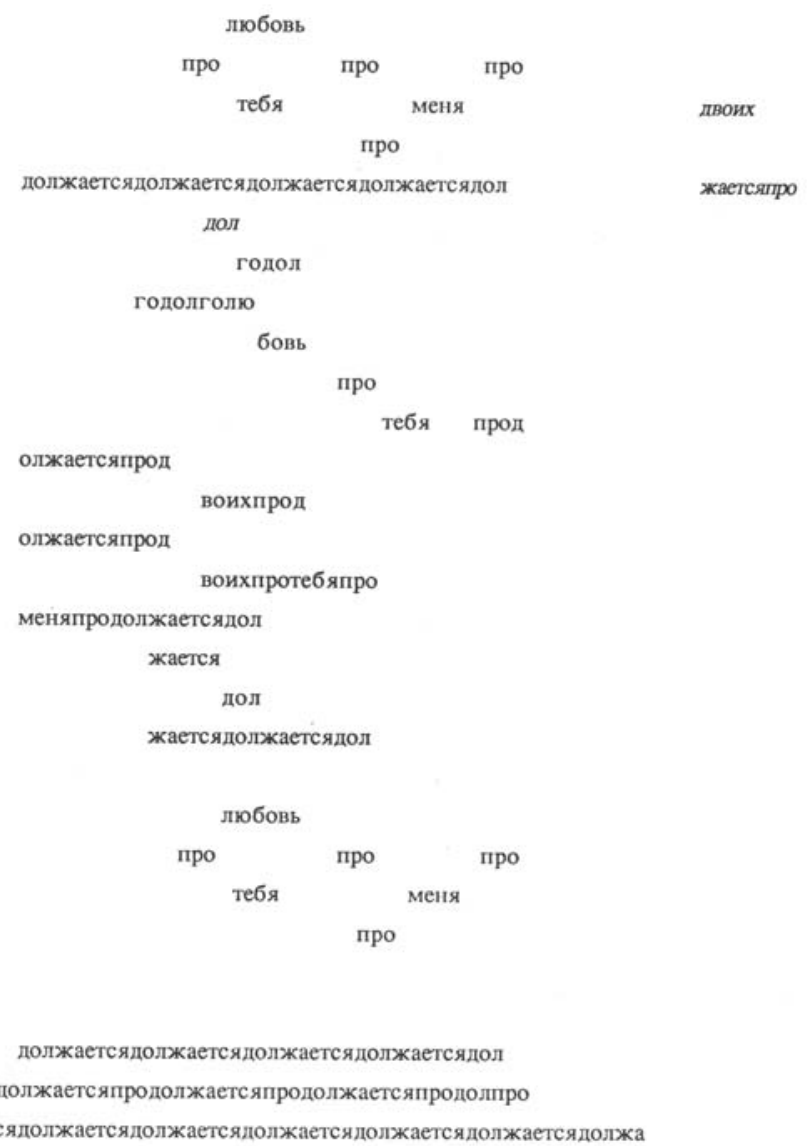

Figure 6. Elisabeth Netzkowa (Mnatsakanjan), Das Buch Sabeth, last poem "Das Hohelied," 151. Courtesy Elizaveta Mnatsakanova.

three lines out of the prefix pro from the word prodolzhaetsia (continues): it becomes the preposition pro, emphasizing this poem is "about you" and "about me" (pro tebia and pro menia). In the handwritten version of this page, the script rejects the elegant calligraphy usually preferred by the poet. It suggests intensity and perhaps even desperation, an insistence on continuation despite fear of rupture and loss (figure 7 ). In the typed version of this page (figure 6), we notice how the last lines of continuation have multiplied, thickened, suggesting not a wall but a floor, a bottom to the spatial dimensions of these texts. ${ }^{60}$

60. The contrast between continuation and cessation is also realized at the formal level of the poem, particularly in the finale to Das Buch Sabeth. Unlike her other long works, "Das Hohelied" is not broken into numbered one-page poems, and yet it is not presented as a single continuous whole: what look to be twenty-three single poems, one per page, without titles or separation markers, ask to be read separately, but without sharp breaks, without beginnings and endings. This formal trait was noted in an early response to Das 


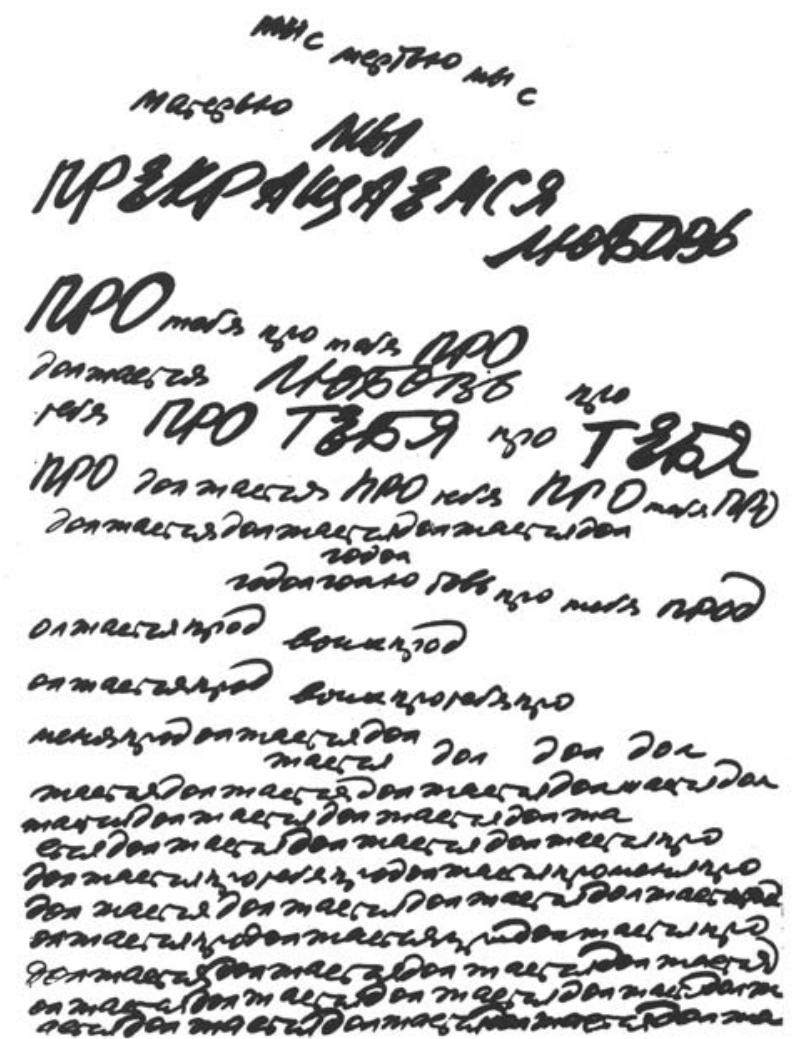

Figure 7. Elisabeth Netzkowa (Mnatsakanjan), Das Buch Sabeth, unpaginated image; also found in Elisabeth Netzkowa (Mnatsakanjan), Das Hohelied: Bilderzyklus zum 5. Teil-Finale-des Gedichtbandes DAS BUCH SABETH, unpaginated. Courtesy Elizaveta Mnatsakanova.

The poet's varied and expressive handwriting, alongside her decision to make her albums by hand, allegorizes both the insistent individuality of the creative act in Mnatsakanova's view of poetic work and her allegiance to Khlebnikov's legacy. Mnatsakanova has described the meaning of handwriting in Khlebnikov's writings. She noted that Khlebnikov and Aleksei Kruchenykh, in "Bukva, kak takovaia" (The letter as such) emphasize the semantic value of a person's handwriting and they hoped for books that would be "letter perfect." ${ }_{1}$ The words' emotions would be felt by a reader

Buch Sabeth by Aleksandr Sekatsii, "Poema i mantra." Sekatsii wrote that he was not sure whether he was reading one long poema or individual lyric poems, but he was sure that this was one of the best books of poetry in the Russian language. His essay valuably concentrates on the theme of death in Das Buch Sabeth, particularly the linguistic transformations around that theme.

61. "Bukva, kak takovaia," in Khlebnikov, Sobranie sochinenii, 6.1:339-42. For a translation, see Velimir Khlebnikov, The King of Time: Selected Writings of the Russian Futurian, trans. Paul Schmidt, ed. Charlotte Douglas (Cambridge, Mass., 1985), 121-22. 


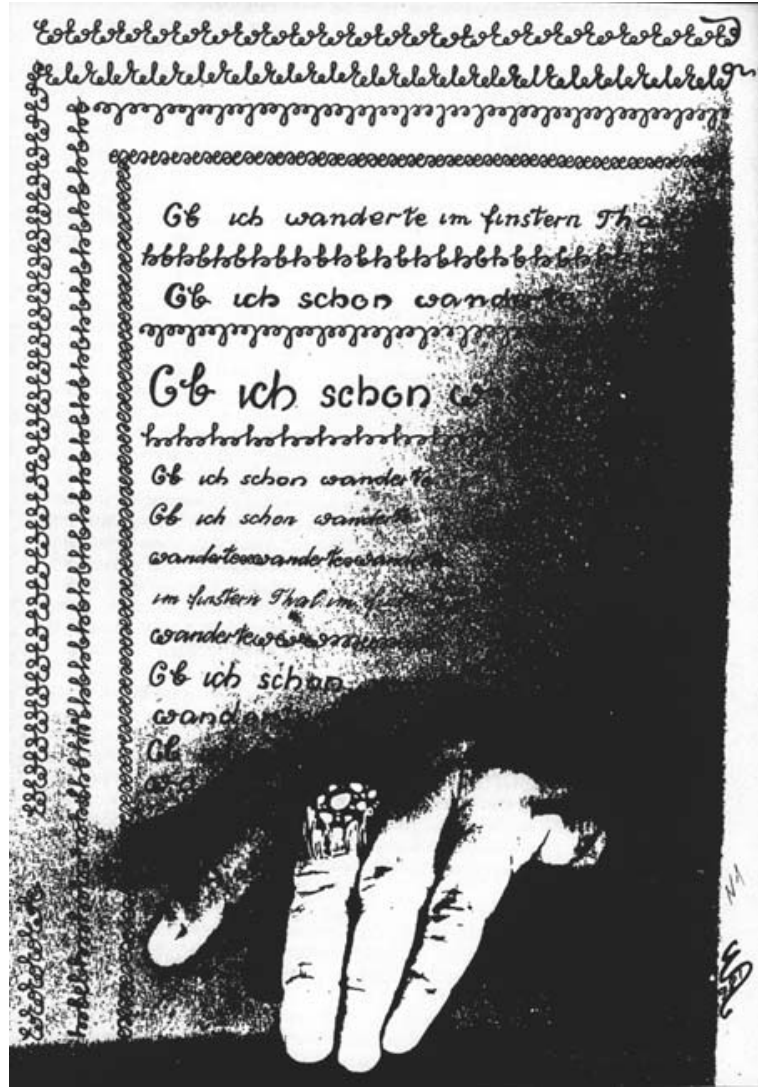

Figure 8. Elisabeth Netzkowa (Mnatsakanjan), Osen' $v$ lazarete nevinnykh sester: Rekviem v semi chastiakh, album with translation by Gerald Janecek, produced by Gerald Janecek under the direction of the poet, 2004, unpaginated. Courtesy Elizaveta Mnatsakanova.

as if the hand of a blind man had passed over the pages, so that the intensity of the act of writing poetic words would be matched by a reader's emotions at (literally) handling the printed text. This desired reading experience returns us to questions of sensory input, and it does so by adding a further layer of sensory impression. Handwriting can complement the reader's engagement via sight and sound with a haptic experience, or something very like one; Mnatsakanova asks the reader to imagine that the emotions of the writing can be transmitted by touch. She invites the reader to think about what it would be like to write these words, to commit words to the page in such varying degrees of control or rapture.

She extends this invitation with the image of a hand. It appears often in albums for Rekviem and on the covers for Metamorphosen (figures 8, 9; compare the hands in figure 1). This hand links in a beautiful metonymy the hand that would feel the perfect letters of a futurist book with that of the writer about to put words on the page. Mnatsakanova positions the 


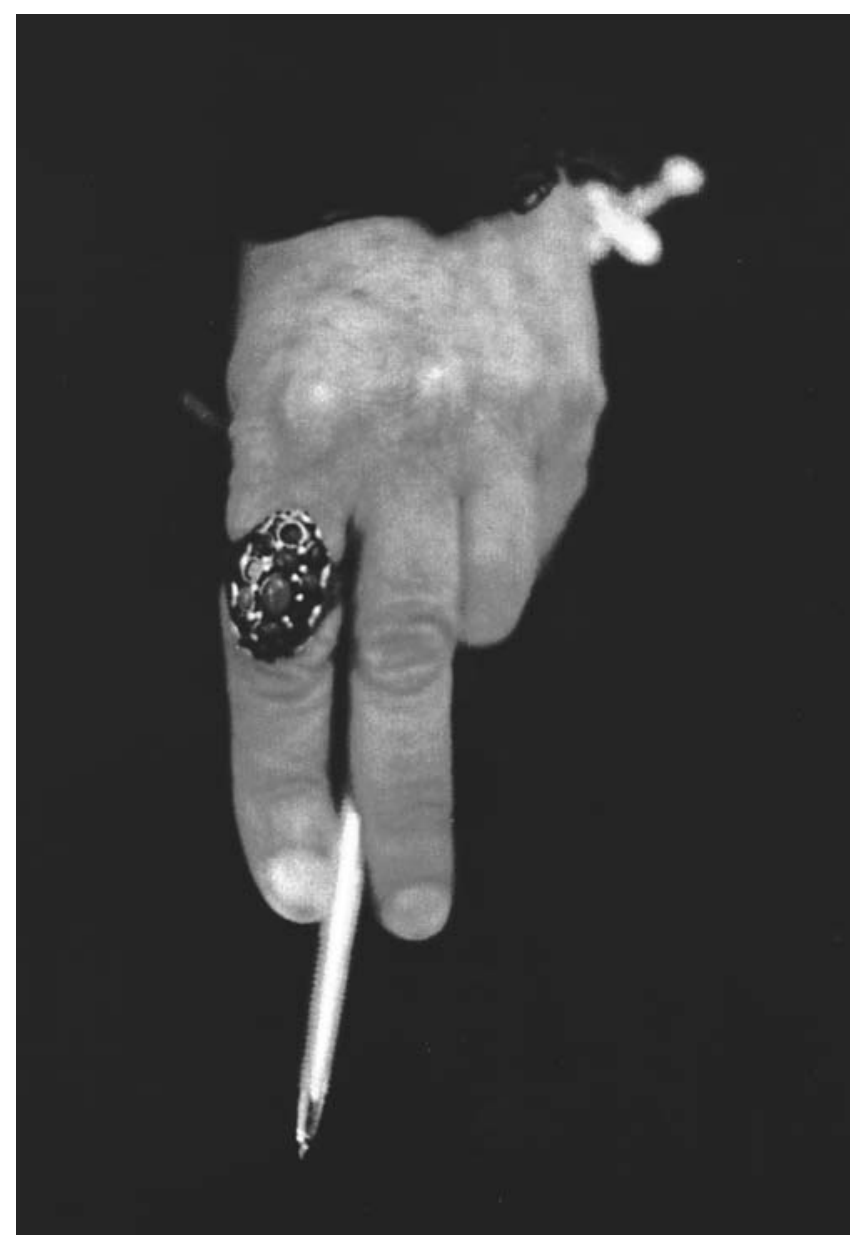

Figure 9. Elisabeth Netzkowa (Mnatsakanjan), Osen' v lazarete nevinnykh sester: Rekviem v semi chastiakh, album with translation by Gerald Janecek, produced by Gerald Janecek under the direction of the poet, 2004, unpaginated. Courtesy Elizaveta Mnatsakanova.

hand variously: it can be poised in midair as if it were the reader's own hand, holding a book or holding a pen to write in the book; it can be a visibly feminine and bejeweled hand whose pen, depending on how the poet places the image, points upward toward something divine or downward toward the all-too-human page of the text (figure 9). The hand is imprinted with the poet's personality, with the specificity of her lived emotions and her vision of poetry, as is the handwriting she so extols. In its specificity, it becomes an image that hopes to mark her difference from Khlebnikov as much as her acceptance of the terms of his legacy.

The hand is also, and perhaps more importantly, an index of the poet's labor. Mnatsakanova tells the story of having first used the image of the hand in her work because of accidentally photocopying her own hand 
while at work printing pages for one of her books. The repeated image reproduces this moment of labor and chance, condensing in a single visual form reference to the poet's work using her hands and to the dependence on photocopying technology that made her self-published books (and much of her art) possible. Benjamin's notion of how reproducible images and books would challenge the possibility of attaining the aura of an original art work seems almost too perfectly invoked by the poet's use of this image and of photocopying technology more generally. He had feared that reproductions would make it harder to experience "the here and now of the work of art," and yet, in Mnatsakanova's work, the opposite seems true. ${ }^{62}$ She offers a lucid, ironic acknowledgment of her dependence on mechanical reproduction with the sign of the hand, which appears in her one-of-a-kind handmade books and in the printed pages she has created in Vienna and in those she has published in Moscow (a hand holding a pen appears on both the front and back inside covers of Arcadia).

The very existence of handmade, one-of-a-kind books alerts us to the poet's desire to recreate for readers an authentic, ritual-based, unrepeatable aesthetic experience. She makes this happen, not via the shock of the new, but in the encounter with similar forms of stimulus, changed subtly and meaningfully. The imagination is to be engaged in repeated contemplation of like phenomena that, ever so slightly, move their position on the page, shift the shape of their letters, vary the color of their borders. Mnatsakanova's commitment to creating this experience for readers present and future is fundamental to her aesthetic philosophy. How many poets would spend decades of their life making (similar, but always somewhat different) one-of-a-kind books? In an era of simulacra and internetavailable duplicates, Mnatsakanova's work resists the devaluation of the book and affirms the pleasures of holding, beholding, touching, and allowing the eye and the ear to slowly absorb her visual poetry.

\section{The Pleasure of the Visual Poem}

One comes, then, to a paradoxical conclusion, that the poet whose work existed for so long in isolation, and the poet who writes of death, loss, separation, and trauma, is engaged in a form of poetic production that seems glad of the arrival of a reader and that assumes that the difficulty of her work will not be entirely forbidding. One image that allows those expectations to emerge in the books is that of the poet's own face. ${ }^{63}$ She presents an image to her readers that is open and alert to the world. It is a frank gaze, one that models for readers the kind of absorption and comprehension she hopes her work will enable. The image regularly seen in the albums is a close-up of the poet's face, based on a snapshot taken several decades ago (figure 10). In this example, the face becomes one

62. Benjamin, "The Work of Art," 4:253.

63. How a face emerges in poetry that works so hard to suppress conventional signs of the lyrical subject is itself a fascinating topic, one that is also important in studying Khlebnikov. See, for example, his famous zaum' poem, "Bobeobi," which suggests the creation of a face in its references to lips, brow, and so on and ends with the lineation of a face appearing on canvas: Khlebnikov, Sobranie sochinenii, 1:198. 


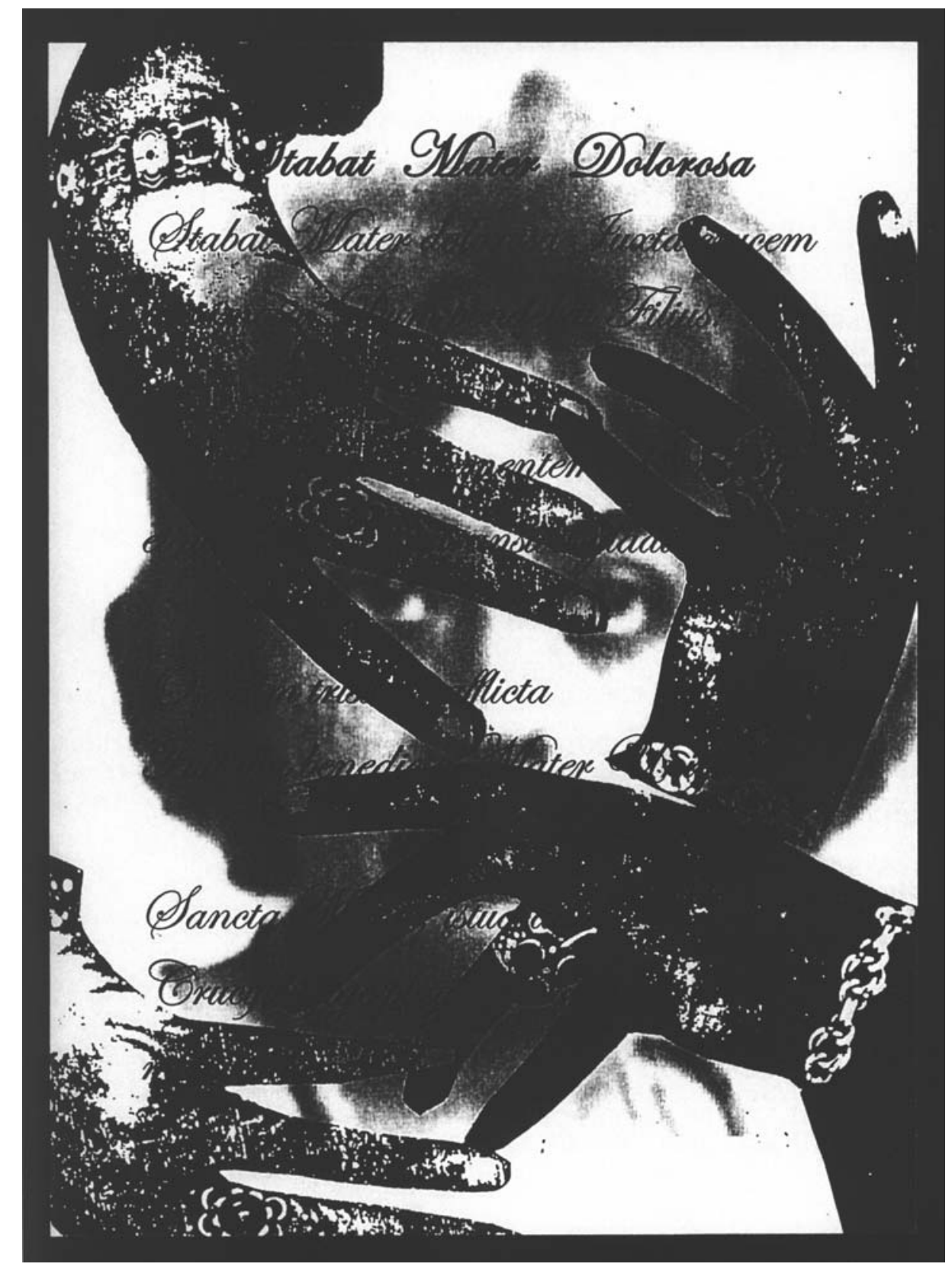

$\oplus$

Figure 10. Elisabeth Netzkowa (Mnatsakanjan), Osen' $v$ lazarete nevinnykh sester: Rekviem $v$ semi chastiakh, album with translation by Gerald Janecek, produced by Gerald Janecek under the direction of the poet, 2004, unpaginated. Courtesy Elizaveta Mnatsakanova. 


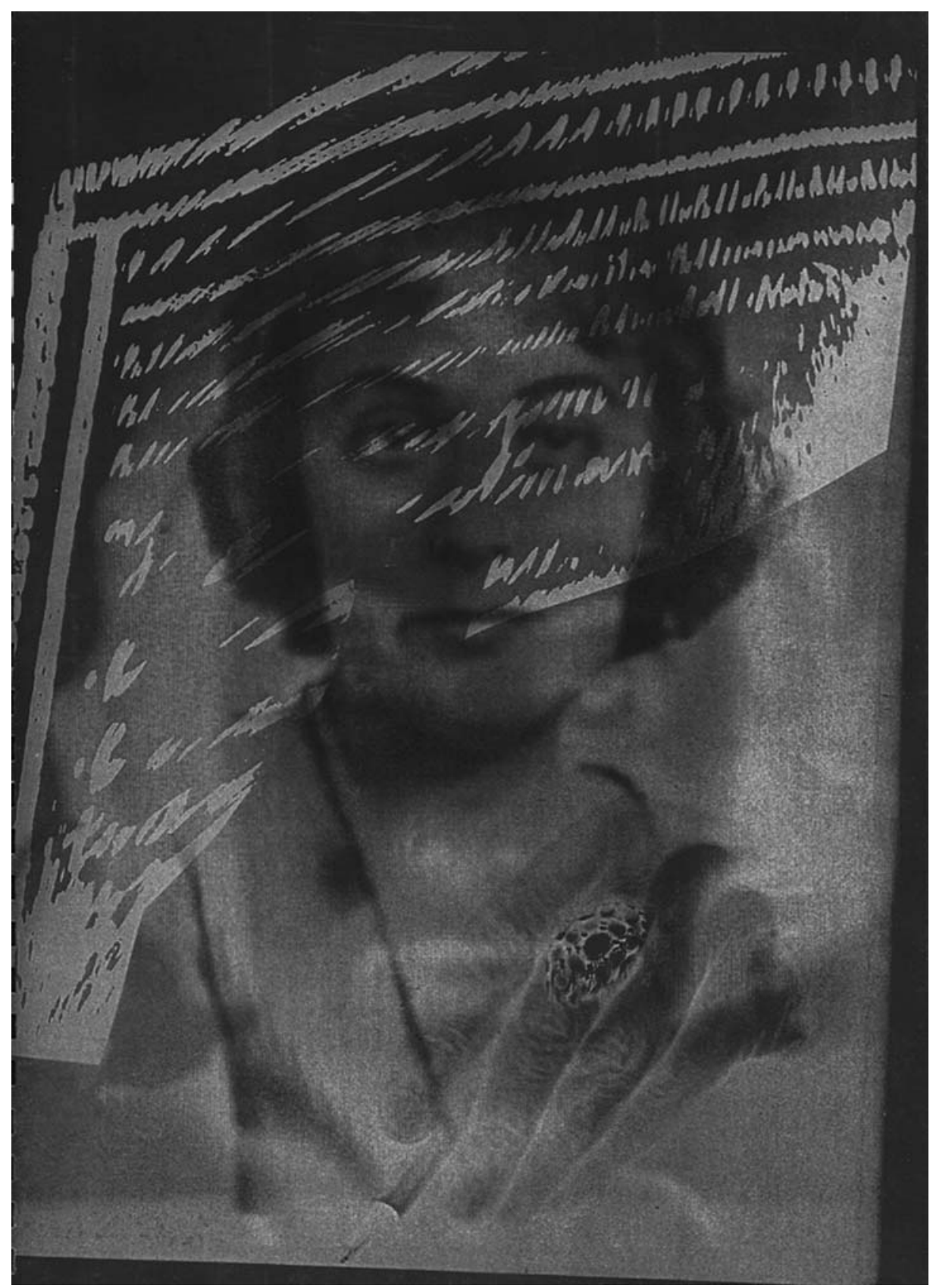

Figure 11. Elisabeth Netzkowa (Mnatsakanjan), Das Hohelied, unique album, unpaginated, *2006M-7 box 1, Houghton Library, Harvard University. By permission of the Houghton Library, Harvard University. 
among several layers of images, partly hidden by a web of hands, and serving as background to lines of Latin text in script. In an image from an album of "Das Hohelied" (figure 11), the poet has placed a transparent sheet of plastic as an overleaf, separating the veiling layer from the actual photograph. The veil is composed of lines of writing rendered illegible by movement - this movement mimics the possibility of another copying error. Accident or no, the image literalizes the impression of movement that the poet's words can create in her lines of text, and it seems both carefully chosen and a result of serendipity.

The poet pays attention to the look of her face in a striking passage that opens "Das Hohelied" (figure 12; compare figure 13, the handwritten version). On its first page, in its first poem, this text gives prominence to the act of smiling. The poet repeats the word ulybaius' (I smile), mixing it on the first page with other verbs prefixed by "u," all seemingly conjured by its sound. ${ }^{64}$ But the smile itself seems to emerge from the poet's own face, in fact it is the probable object of description in the opening line, "a skull split in two" (raskolotym nadvoe cherepom). ${ }^{65}$ To say that a smile splits open the bones of the face is violent and perhaps shocking. Mnatsakanova has a useful forebear in this mix of the grotesque and the pleasurable; her reference to a split skull in this prominent initial position recalls Khlebnikov's use of that image in the opening of his play Oshibka smerti (Miss Death makes a mistake, 1915). ${ }^{66}$ His play is part parody, and the split skull is presented as a vessel for drinking in a tavern. Mnatsakanova's text can similarly mix tonalities, although without a sense of parody. Amid deathly images and references to separation and love, the poet's recurring smile may seem ghastly. And yet the smile has multiple explanations in her poem. It can be a brave response to a lover's departure, a satisfied acknowledgment that one's words have grappled successfully with the challenge of this poem, or a disarming shudder of a smile that welcomes reader and lover alike into the shifting landscape of this Song of Songs.

None of these contexts is fully created in the poem, save perhaps the last, for indeed one does sense the poet's happy knowledge that her poetry, against all the odds, is destined for some form of success. The act of smiling is not so much a performance as an act of engaging an other; those who have met the poet can testify to the powerful effect of her radiant smile. On the first page of "Das Hohelied" (figures 12, 13), we find a smile that freezes into a trapped space, caught among declensions of the personal pronoun $t y$. It matters that this smile is a verb, rather than a

64. These verbs include: "I drink," "I am surprised," and, in later pages, "I grow smaller," "I swim off" (upivaius', udivliaius', umen'shaius', uplyvaiu). They vary semantically, but the direction of moving is always as if in departure or toward diminishment.

65. Mnatsakanova, Das Buch Sabeth, 129.

66. For the English, I use the title brilliantly devised by Paul Schmidt in his translation of the play published in Velimir Khlebnikov, The Collected Works of Velimir Khlebnikov, ed. Ronald Vroon (Cambridge, Mass., 1989), 2:252-58. For the Russian, see Khlebnikov, Sobranie sochinenii, 4:227-36. The play is dated 1915 according to the manuscript; it was first published in 1917. This play is conceptually important for Mnatsakanova's Beim Tode Zugast as well. 


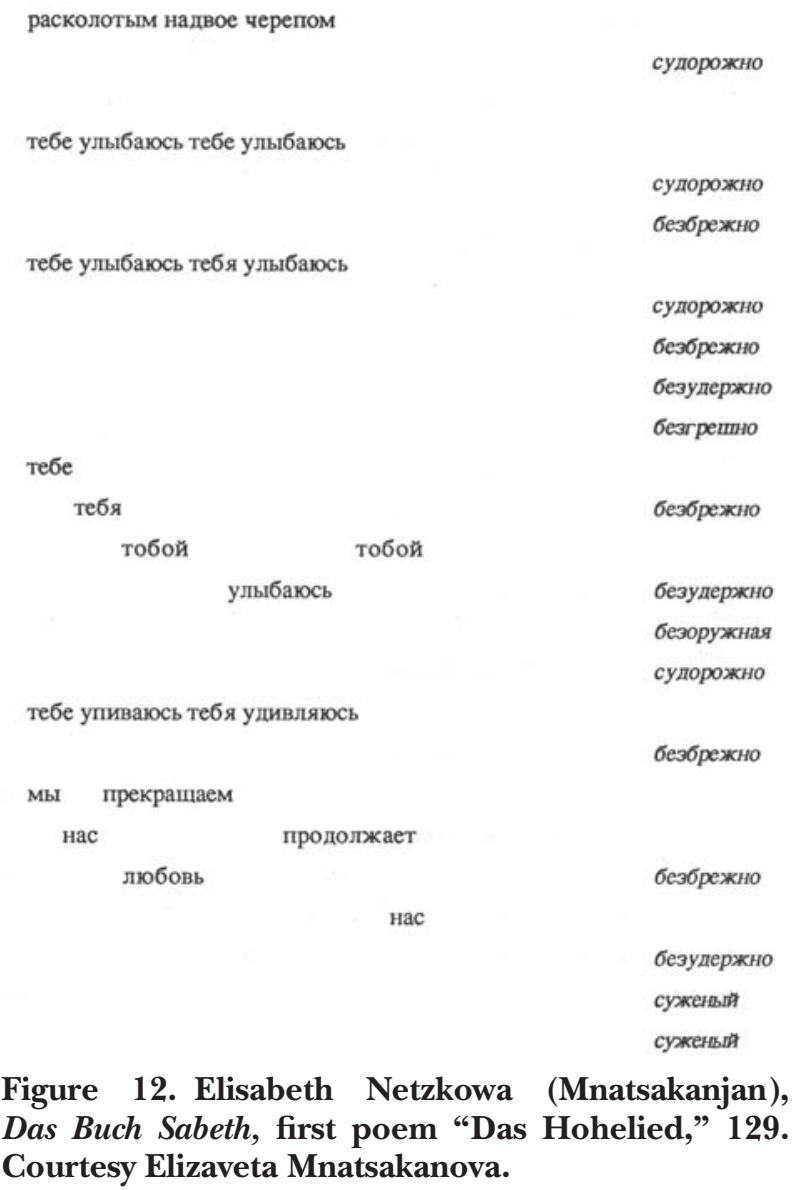

noun; it is the admission or announcement "I smile" (ulybaius'). I smile at you, I smile upon you, I smile by means of you, and the adverbs that line up in the right-hand column conjure up a smile that can be careless or innocent, but may also be a kind of shudder: "convulsively," "carelessly," "sinlessly" ( sudorozhno, bezbrezhno, bezgreshno). The spasms suggested by the word sudorozhno are the most expressive; they leave the act of smiling in some sort of hapless involuntary state. ${ }^{67}$ The act of imbibing the other, getting drunk on the other, is exceeded only by being surprised by the other, and in both cases the speaker exudes great intensity in emotion. The self cannot but be destabilized by this inebriating shock. The smile has come to be something like what Kevin Newmark has called the "shock of laughter" in Charles Baudelaire; his words open as well a productive

67. The act of smiling is also performed "impetuously" (bezuderzhno), another way of saying that the poet smiles to show her lack of restraint. That diminished sense of agency is found in two other verbs, "I drink" and "I am surprised" (upivaius', udivliaius')—note that the "u" sound of these prefixed verbs is echoed in the stressed "u" sound of sudorozhno and bezuderzhno. 


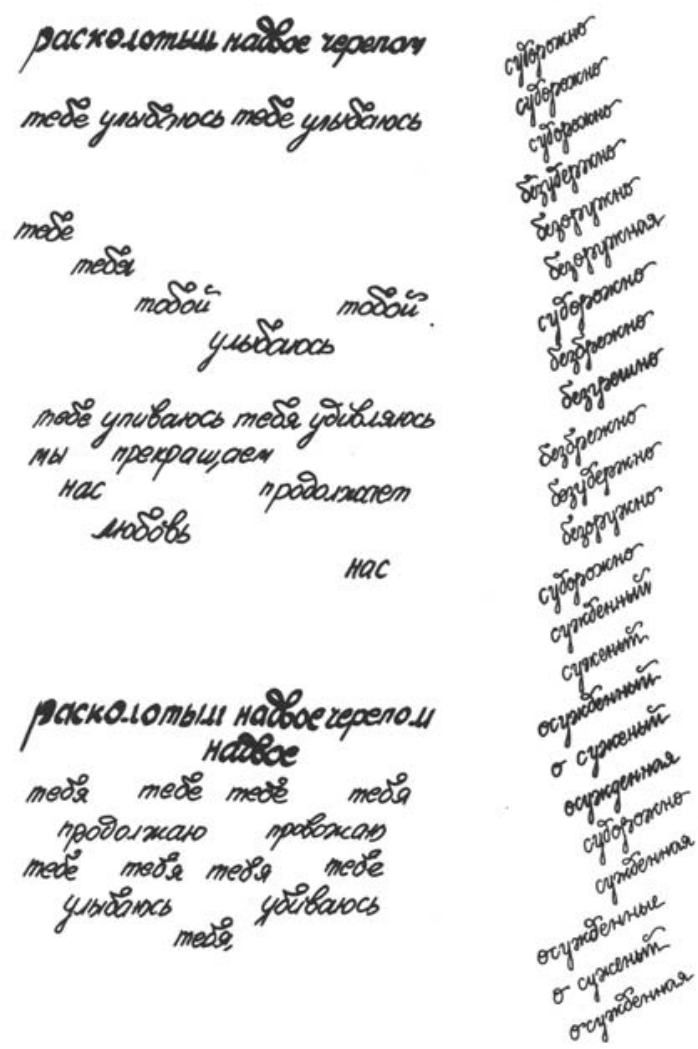

Figure 13. Elisabeth Netzkowa (Mnatsakanjan), Das Buch Sabeth, unpaginated image; also found in Elisabeth Netzkowa (Mnatsakanjan), Das Hohelied: Bilderzyklus zum 5. Teil-Finale-des Gedichtbandes DAS BUCH SABETH, unpaginated. Courtesy Elizaveta Mnatsakanova.

approach to the work of Khlebnikov, not least in his famous poem "Incantation by Laughter." 68

Like Khlebnikov, Mnatsakanova revels in this intensity, in the joy of word creation, in the pleasure in the text. There is pleasure as well in the recreation of the encounter with the beloved, an encounter that is couched in the terms of folklore. She is, in the single feminine adjective that appears in the column of adverbs, a disarming girl (bezoruzhnaia). Her defenselessness is enacted rather than confessed, and it is not reduced by the gestures that create barriers - the words that border many

68. Kevin Newmark, "Traumatic Poetry: Charles Baudelaire and the Shock of Laughter," in Cathy Caruth, ed., Trauma: Explorations in Memory (Baltimore, 1995), 236-55. "Zakliatie smekhom" surely stands as a subtext to the spasms of laughter imagined on this page of poetry, and the intensity and rupture of the laugh account in turn for the violence of the skull split open. 
of the pages, and the barrier of fractured speech itself. Nothing weakens the strong attraction she feels toward the man she calls, in the dedication, an unseen friend (Nevidimyi Drug) ${ }^{69}$ On this page, he is present as the one masculine adjective, the bridegroom (syzhenyi), the one who is intended for her, out of Russian folk culture with all its suggestions of ancient inevitability. ${ }^{70}$ The eternity of this bond is reinforced by the folkloric language. There is a curious parallel between the repeated phrase "love is continuing" and the poem's having been composed in a single day. ${ }^{71}$ The desired temporality is that of eternity, a spatial reconfiguration of time where endlessness can be imagined and where the beloved need never be entirely released. The poet who makes multiple versions of "Das Hohelied" also enacts that refusal to let go.

We are left, then, with the joy in the repeated production of the book. Das Buch Sabeth has existed in many versions since before the poet's emigration to Vienna in 1975, and in these changes it is typical of the poet's work, rather than unusual; compare the many album versions of her most famous poem, "Osen' v lazarete nevinnykh sester" (Autumn in the lazaretto of innocent sisters).$^{72}$ Mnatsakanova's decisions to transfer her artworks and books to a Vienna museum and to a university archive, her agreement to Russian publications of her work, her recording of a videotape and two compact disks of her poetry readings, and her arduous labor creating exhibits of her work for several decades and in cities near and far all make clear her desire to have her work read and seen. She is not, in the end, so much like Khlebnikov, with his indifference to his manuscripts. Rather, she resembles Belyi, whose massive revision of his poetry demonstrated a similar concern for returning to earlier work, and a wish to see that work change form and appearance as his own poetic principles were changing. Mnatsakanova could take much, in fact, from the specific nature of Belyi's revisions: he fundamentally experimented with the visual layout of his poetry. His columns of words often emerged in these revisions. The change is striking in lyric poems that shed their quatrain format in favor of columns of mostly single words. ${ }^{73}$

69. Mnatsakanova, Das Buch Sabeth, 152.

70. At this stage of Das Buch Sabeth, we have the shock of the encounter but not, perhaps, the shock of loss. That appears in the two poems added into "Laudes" (in pages that are dense with words that almost shout with outrage and loss). The fiercer tone, as well as the imperative "thou shall not forget" (ne zabud') mark these two poems as memorials, as the poet herself has noted. Elizaveta Mnatsakanova, telephone conversation with the author, 2 December 2004. It is entirely consonant with the poem's rejection of conventional temporality that Mnatsakanova would not have added in those poems at the end of Das Buch Sabeth, preserving "Das Hohelied" instead as a place where the beloved may be unattainable but he is not to be taken away.

71. Composed on a single day, from first thing in the morning until some twelve hours later. Elizaveta Mnatsakanova, telephone conversation with the author, 2 December 2004.

72. When the poem appeared in a Moscow journal publication, Mnatsakanova added a new preface and made some further changes. Gerald Janecek also translated this poem, in a photocopied edition of 2004 he created with the use of images provided by the poet, three of which are included here (see figures 8-10).

73. For examples, see Lavrov, "Ritm i smysl," 35-37. This sense of revision could occur even within a poem, as Gasparov has shown in his analysis of the framing verses 
Repetition and return, then, are also key features of the legacy Mnatsakanova received from Belyi. This works at the level of the poetic text, where repetition of sounds and words organizes the reader's experience, and as a feature of the poet's creative biography. Like Belyi, Mnatsakanova is a poet who revises and rethinks, one whose creative work stretches over many years and drives her to change texts and images every time she returns to a given text. In effect, she offers this process of revision and rethinking to her readers when she makes new versions of her poems: another revision, or a different album, always awaits the reader. Compare the large-scale project El'moli, begun more than two decades ago, which remained incomplete for many years. Now it is finished, to appear in Moscow in 2008.

One is left, then, with a final question, about the legacy of Mnatsakanova's own work and about the ways in which the approach to her work, set forth here, might be useful in reading others. It is striking how the champions of Mnatsakanova's work have come, for the most part, from the ranks of Russian poets and thinkers-Vladimir Aristov, Aleksandr Skidan, Il'ia Kukulin, among them. How productively her example inspires the efforts of these and other poets, as her work at last becomes more widely available, remains to be seen. Aristov, however, dedicated a poem to her in 1996 in which he credits her with making available the prototypes of an epoch, its negatives, with the regal touch of her hand, and her pen. ${ }^{74}$ The sensuous experience of her work teaches lessons about the past, he is telling us, and perhaps it can foresee poetry's future as well. His reference to the poet's pen, like the metonymy that emphasizes her hand in so many of her books, reminds us that the work of poetic creation is foregrounded in this poetry, as is the reader's work of responding to the sensory multiplicity of the poems. To call this visual poetry is to give pride of place to the capacities of the eye. Yet the poems themselves and the books in which they appear invoke quite powerfully a reader's senses of hearing and touch. As we must divide our mind's attention to absorb these poems, so must we, as scholars, divide our attention among predecessor poets. When we recognize the multiple influences on this one poet, we are also setting up the possibility for greater complexity, and greater pleasure, in our readings of her contemporaries - and her successors.

in the ballad "Shut"; but Gasparov concludes that Belyi's experiments with changing the visual look of poetry in order to communicate to readers information about the melody and intonation of a verse line were "tragically fruitless." Gasparov, "Belyi-stikhoved i Belyi-stikhotvorets," 3:434.

74. Vladimir Aristov, "Prototipy epokhi, ee negativy," in Inaia reka (Moscow-St. Petersburg, 2002), 5-6. 